\title{
The Growth of Interventional Pain Management in the NeW Millennium: A Critical Analysis of Utilization in The Medicare Population
}

\author{
Laxmaiah Manchikanti, MD
}

Interventional pain management has been growing by leaps and bounds with the introduction of an array of new CPT codes, the expansion of interventional techniques, and utilization. Interventional pain management dates back to the origin of neural blockade and regional analgesia, in 1884. Over the years, pain medicine and interventional pain management have taken many approaches, including biological, biopsychosocial, and psychosocial.

In the late 1990 s and early 2000s, a new philosophy of precision diagnosis and hightech management has evolved. An interventional pain physician may be either a reductionist, a monotherapist or a combination of the two. Interventionalists have been criticized for excessive undisciplined application of needle procedures.

The National Uniform Claims Committee (NUCC) defined interventional pain management as the discipline of medicine devoted to the diagnosis and treatment of pain and related disorders with the application of interventional techniques in managing subacute, chronic, persistent, and intractable pain, independently or in conjunction with other modalities of treatments. The Medicare Payment Advisory Commission (MedPAC), in its report on access to interventional pain management services, described interventional techniques as minimally invasive procedures, such as needle place-

From Pain Management Center of Paducah, Paducah, Kentucky

Address Correspondence: Laxmaiah Manchikanti, MD, 2831 Lone Oak Road, Paducah, Kentucky 42003

Disclaimer: There was no external funding in preparation of this manuscript.

Conflicts of Interest: None

Manuscript received on 9/02/04

Revision submitted on 9/30/04

Accepted for publication on $9 / 30 / 04$
Interventional techniques are performed by many primary specialists (anesthesiology, physiatry, neurology, etc.) and physicians designated by CMS in interventional pain management (-og) and pain management or pain medicine $(-72)$ which went into effect in 2003 and 2002.

Overall, the frequency of utilization of interventional procedures has increased substantially since 1998 . It is estimated that among Medicare recipients, the frequency of interventional procedures, which includes epidural, spinal neurolysis, and adhesiolysis procedures; facet joint interventions and sacroiliac joint blocks; and other types of nerve blocks, excluding continuous epidurals, implantables, disc procedures, intraarticular injections, trigger point and ligament injections, had increased by $95 \%$ from 1998 to
2003. In the Medicare population, facet joint interventions and sacroiliac joint blocks have increased by $222 \%$ from 1998 to 2003 . Overall, the utilization ofvarious nerve blocks (excluding epidurals, disc injections, and facet joint blocks) in Medicare recipients from 1998 to 2003 were performed approximately $50 \%$ of the time by non-pain physicians.

Interventional pain management is growing rapidly, under the watchful eye of the government, and third party payors. Establishing an algorithmic approach and following guidelines may improve compliance and quality of care without implications of abuse.

Keywords: Interventional pain management, pain medicine, utilization, clinical effectiveness, cost effectiveness, algorithmic approach, precision diagnosis, precision treatment ment of drugs in targeted areas, ablation of targeted nerves, and some surgical techniques, such as diskectomy and the implantation of intrathecal infusion pumps and spinal cord stimulators.

In the new millennium, interventional pain management has seen the introduction of an array of new CPT codes and the expansion of interventional techniques. Coupled with this progress, interventional pain management physicians have inherited a multitude of problems, which include controlled substance use and abuse, issues related to coding, billing, documentation, and excessive utilization along with allegations of fraud and abuse.

\section{Historical Considerations}

Interventional pain management dates back to the origins of neural blockade and regional analgesia. Fundamental to modern neural blockade and interventional techniques is the concept that pain is a sensory warning conveyed by specific nerve fibers, amenable, in principle, to modulation or interruption anywhere on the nerve's pathway. The concepts of neural blockade and interventional techniques are founded on the structural basis of chronic pain.

The origins of neural blockade and regional anesthesia date back to September 15, 1884, when Koller (a colleague of Sigmund Freud) reported the numbing effect of cocaine on the tongue (1). This observation took the world by storm. By the year's end, cocaine was used to provide effective local anesthesia for ophthalmology, urology, and general surgery. In 1899, Tuffer (2) described a therapeutic nerve block in pain management, using spinal cocaine to control pain from sarcoma of the leg. Further progress was advanced with Cushing's (3) description of pain relief with nerve blocks, description of caudal epidural injections in 1901 (46), report of trigeminal alcohol blockade by Schloesser (7) in 1903, and thereafter by a rapidly growing list of other interventional techniques (8-45).

Diagnostic blockade in pain management was pioneered when von Gaza (46) used procaine for determining the path- 
ways of obscure pain (sympathetic or sensory). Following this, White (47) in 1930, and Steindler and Luck (48) in 1938, described applications for diagnostic interventional techniques.

The presumed futility of treating pain without localizing the pain generator prompted Steindler and Luck (48) to employ procaine hydrochloride injections for identifying specific sources of pain in low back pain disorders. The application of clinical anatomy and an appreciation of the structural basis of spinal pain revolutionized diagnostic interventional techniques. Recent advances in our understanding of key principles of clinical anatomy of the spine, particularly for interventionalists, are credited to Bogduk and others $(25,49-63)$.

\section{EVOLUTION}

Over the years, pain medicine and interventional pain management have taken many approaches including biological, biopsychosocial, and psychosocial. Each approach has its proponents and opponents. However, no single approach to the treatment of chronic pain has been validated. Consequently, almost all specialists agree that chronic pain and its management are too complex to be reduced to a single opinion or a single modality universally acceptable. From a historical perspective, the oldest strategies for managing chronic pain, particularly chronic low back pain, are conservative modalities and surgical interventions, which may be described as monotherapy. However, in the 1980s, the strategy of utilizing one modality of treatment in isolation, followed by a trial of another modality if the first one did not succeed, and finally leading to surgery has been challenged. Consequently, biopsychosocial approaches developed, which involved not only physical, but also psychological and behavioral management.

It was again recognized that conservative therapy, surgery, and even behavioral approaches did not work for some patients (64). This prompted innovations in the form of "high-tech treatments." Spinal cord stimulation and intraspinal drug delivery systems are hallmarks of these modalities. However, these also were considered as monotherapies. Even though these were high-tech interventions, they were also based on the principles of multidisciplinary therapy or behavioral therapy, without specific patho- anatomic diagnoses. Thus, treatment was considered symptomatic, without the requirement for a diagnosis.

In the late 1990s and early 2000s, a new philosophy of precision diagnosis and high-tech management evolved. Bogduk described this as reductionism (64). This strategy assumed that patients with chronic back pain did have a lesion, but it was not being diagnosed. As a result, conservative therapies and even surgery were being applied empirically and without attention to identifying a valid diagnosis. It was considered to be the main reason for the failure of many interventions. Further, many felt that it was inappropriate to conclude that all these patients needed behavioral therapy. Consequently, the objective of the reductionist strategy is to pin-point the source of pain and to stop the pain.

Bogduk (64) described a tri-polar system involving all three approaches. One pole is persistence with monotherapies - being single types of treatment delivered often by a single physician, and which includes non-surgical and non-interventional therapies, traditional surgery, and high-tech interventions. The second pole is multidisciplinary behavioral therapy - using multiple interventions, delivered by a team of professionals, but focusing on psychological distress, beliefs, attitudes and physical performance, rather than on pain. The third pole is the reductionist strategy, which involves finding the source of pain, with a view to stopping it. Thus, a simplified description of an interventional pain physician may be either a reductionist or a monotherapist, or a combination thereof. Of course, purists may believe that none of the other techniques work, except the one they believe in.

\section{Interventional Pain Management}

Interventionalists have been criticized for performing only needle procedures or, according to some, for abusing them. The reductionist approach faced criticism mainly for the undisciplined application of needle procedures or interventional techniques (64-66). Many of the diagnostic and therapeutic interventional techniques are based on evidence (67-75). However, some are acquiring a bad reputation due to their use in an undisciplined and unproductive manner, by providers who are not well qualified, and by performing them in inappropriate settings. Inappropriate documentation, lack of medical necessity criteria, and excessive utilization in interventional pain management will continue to be a source of criticism (76).

\section{Documentation}

Few issues in modern medical practice spark as much controversy as insufficient documentation and provision of inappropriate medical services. Documentation is closely interlinked with billing, coding, fraud, abuse, medical liability, and increasing health care costs. Documentation is to provide evidence or information. For physicians, documentation means providing information or evidence on multiple issues, including evaluation and management services, procedural services, billing and coding. If a physician wants to get paid for what was done or stay out of fraud and abuse investigations, one has to follow the dictum document, document and document. Even though healthcare is not so different from other industries and services, documentation has become an inevitable and even desirable part of medical practice (76).

A general accounting office, now known as Government Accountability Office (GAO), study submitted to the Ways and Mean Health Subcommittee on September 25, 2001, showed that Medicare carriers were often wrong and approximately $85 \%$ of the time provided incorrect or incomplete answers. The Office of Inspector General reported overpayments of $\$ 23.3$ billion in $1996, \$ 20.3$ billion in $1997, \$ 12.6$ billion in $1998, \$ 13.5$ in $1999, \$ 11.9$ billion in $2000, \$ 12.1$ billion in 2001, $\$ 13.3$ billion in 2002, and $\$ 11.6$ billion in fiscal year 2003 in the Medicare program (Table 1). It has been demonstrated that increased efforts to prevent fraud and abuse have reduced the Medicare fee-for-service error rates significantly (Fig. 1).

The most important causes of the offensive on physician practices with heightened requirements for documentation are increasing healthcare costs, the Clinton administration, the Health Insurance Portability and Accountability Act (HIPAA) and the Balanced Budget Act.

Error rates also have been determined for Medicare carriers, ranging from $6.1 \%$ to $25.7 \%$ with an average of $14.4 \%$. No such data is available for third party payors.

There is tremendous variation in documentation standards among payors. 
Table 1. Improper payments by type of error

\begin{tabular}{|c|c|c|c|c|c|c|c|c|}
\hline \multicolumn{9}{|c|}{ Fiscal Year } \\
\hline & 1996 & 1997 & 1998 & 1999 & 2000 & 2001 & 2002 & 2003 \\
\hline Documentation errors & $46.8 \%$ & $44.3 \%$ & $16.8 \%$ & $40.4 \%$ & $36.4 \%$ & $42.9 \%$ & $28.6 \%$ & $63.5 \%$ \\
\hline Medically Unecessary Services & $36.8 \%$ & $36.9 \%$ & $55.6 \%$ & $32.8 \%$ & $43.0 \%$ & $43.2 \%$ & $57.1 \%$ & $21.7 \%$ \\
\hline Coding errors & $8.5 \%$ & $14.7 \%$ & $18.0 \%$ & $15.8 \%$ & $14.7 \%$ & $17.0 \%$ & $14.3 \%$ & $12.1 \%$ \\
\hline Noncovered/others & $7.9 \%$ & $4.1 \%$ & $9.6 \%$ & $11.0 \%$ & $5.9 \%$ & $-3.1 \% \star$ & $0 \%$ & $2.7 \%$ \\
\hline
\end{tabular}

* For 2001 the $-3.1 \%$ applied primarily "other" errors. In these cases, medical reviewers determined that the amounts billed should have been higher or that amounts previously denied were correct.

For 2003 , figures have been adjusted to account for non-response problem experienced in 2003.

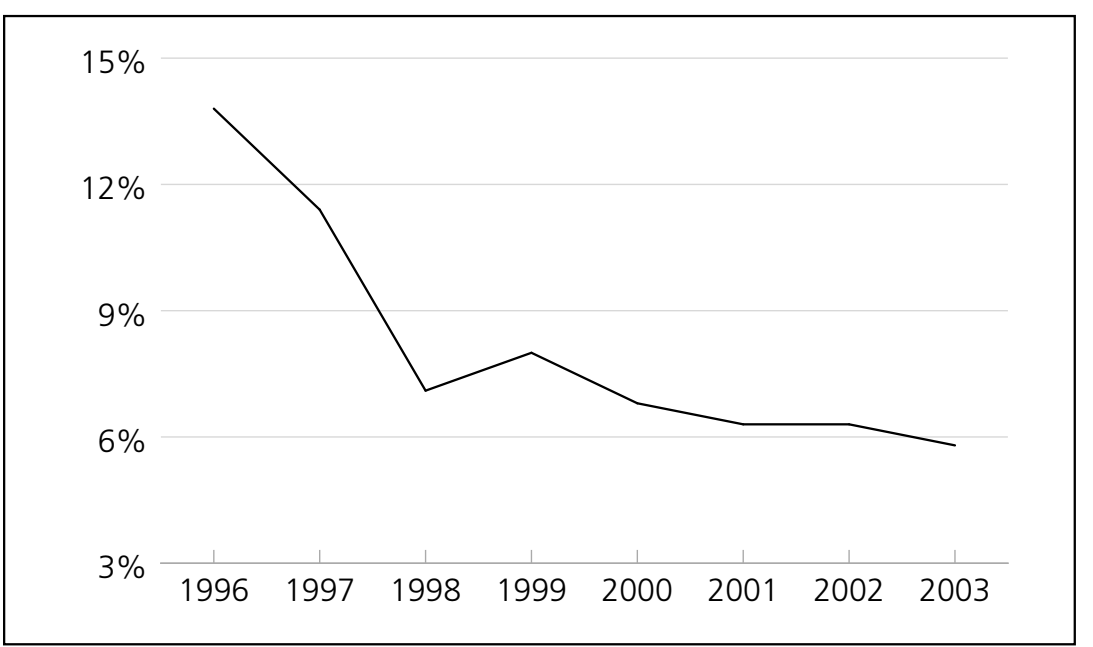

Fig. 1. Medicare fee-for-service (FFS) error rate

Further, the variation is not just among the carriers but even among individual carriers themselves there are regional policies. Even Medicare carriers who are believed to be consistent because they are all under the Medicare administration, publishe varying documentation policies. This also applies to large health insurance companies such as Aetna, Blue Cross and Blue Shield, and United Health Care. Given this great variation, the best way for the physician to entirely meet the documentation criteria is to use a checklist and cover all aspects:

- Should make it clear that the procedure was performed by the reporting or billing physician,

- Document with appropriate and specific diagnostic code such as, ICD-9 CM,

- Provide documentation of indications and medical necessity, which may be reviewed by payors at any time,

- Must document specific regulations governing procedures performed in chronic pain management by many carriers, and

- Follow correct coding initiatives, and Local Medicare Review Policies with the limitations, which become part of documentation.

\section{Medical Necessity}

The Centers for Medicare and Medicaid Services defines medical necessity as ... "no payment may be made under Part A or Part B for any expense incurred for items or services which - - are not reasonable and necessary for the diagnosis or treatment of illness or injury or to improve the functionality of a malformed body member."

The American Medical Association defines medical necessity as, ... "no pay$B$ for any expense incurred for items or services which - - are not reasonable and necessary for the diagnosis or treatment of illness or injury or to improve the functionality of a malformed body member (77)."

The American Medical Association further defines medical necessity as, ment may be made under Part A or Part
"Health care services or products that a prudent physician would provide to a patient for the purpose of preventing, diagnosing or treating an illness, injury, disease or its symptoms in a manner that is: 1 ) in accordance with generally accepted standards of medical practice; 2) clinically appropriate in terms of type, frequency, extent, site and duration; and 3) not primarily for the convenience of the patient, physician or other healthcare provider."

Black's Dictionary of Law, defines medical necessity as "An absolute physical necessity, an inevitability, or convenient, useful, appropriate, suitable, proper or conductive to the end sought".

Quinn (78) defined medical necessity as, "Ideally, it encompasses the shortest least expensive, or least intense level of treatment, care or service rendered, or supply provided, as determined to the extent required to diagnose or treat an injury or sickness".

\section{Local Medical Review Policy}

Local medical review policy (LMRP) is an administrative and educational tool to assist providers, physicians and suppliers in submitting correct claims for payment. Local policies outline how contractors will review claims to ensure that they meet Medicare coverage requirements. The Centers for Medicare \& Medicaid Services (CMS) requires that LMRPs be consistent with national guidance (although they can be more detailed or specific), developed with scientific evidence and clinical practice, and are developed through certain specified federal guidelines. Contractor Medical Directors develop these policies (77).

\section{Local Coverage Determination}

A "Local Coverage Determination" (LCD) is a decision by a fiscal intermediary or carrier whether to cover a par- 


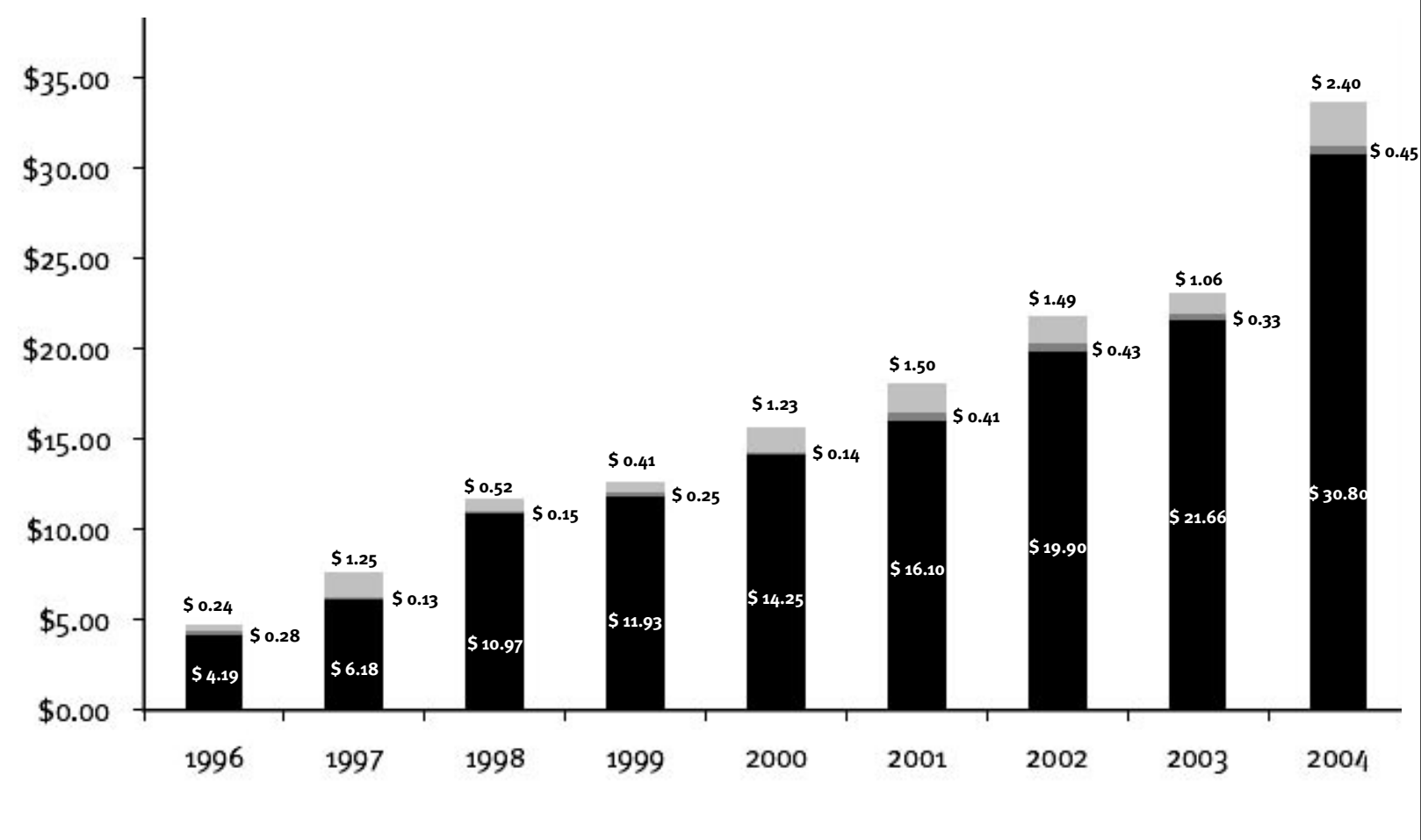

Fig. 2. Cost savings reported by Department of Health and Human Services (DHHS), Office of Inspector General (OIG)

ticular service on an intermediary-wide or carrier-wide basis in accordance with Section 1862(a)(1)(A) of the Social Security Act (i.e., a determination as to whether the service is reasonable and necessary). The difference between LMRPs and LCDs is that LCDs consist only of "reasonable and necessary" information, while LMRPs may also contain category or statutory provisions (77).

\section{Fraud and Abuse}

While the federal government has become far more aggressive in identifying and prosecuting healthcare professionals and entities for fraud and abuse, private insurers also are becoming not only more active but are also pursuing fraud and abuse. Recent Federal Bureau of Investigation statistics show that $60 \%-75 \%$ of investigations are related to government agencies, either Medicare or Medicaid; whereas $25 \%-40 \%$ of the cases are investigated secondary to the complaints of private insurers (79).

For the past 10 years, physician prac- tices have been aggressively audited by the federal and state governments, along with major third-party payors across the nation. Since 1993, there have been a record number of investigations, indictments, convictions and settlements in almost every segment of the healthcare community (79). Figure 2 and Table 2 summarize savings, recoveries, civil and criminal penalties of healthcare fraud. US government fraud and abuse recoveries and savings are estimated at $\$ 115$ per dollar invested or \$9.7 million per each OIG employee.

The government also has recovered significant amounts and returned the funds to the Medicare trust fund compared to the funds appropriated from the federal budget on fraud and abuse. It also has been illustrated that the government's health related civil fraud recoveries have been gradually increasing not only in amount, but also in proportion compared to total civil fraud recoveries.

The OIG's 2004 work plan encompasses significantly increased levels of activity compared to 2003 as follows:
Outpatient Prospective Payment System

- Outpatient services delivered on the same day as a discharge and a readmission

- Procedure coding of outpatient and physician services

- Outlier payments under the outpatient prospective payment system

Table 2. Provider exclusions and criminal convictions.

\begin{tabular}{|c|c|c|}
\hline Year & Exclusions & $\begin{array}{l}\text { Criminal } \\
\text { convictions }\end{array}$ \\
\hline 1996 & 1408 & 151 \\
\hline 1997 & 2719 & 215 \\
\hline 1998 & 3021 & 326 \\
\hline 1999 & 2976 & 396 \\
\hline 2000 & 3350 & 467 \\
\hline 2001 & 3756 & 465 \\
\hline 2002 & 3448 & 480 \\
\hline 2003 & 3275 & 576 \\
\hline 2004 & 3088 & 468 \\
\hline
\end{tabular}

Source: DHHS, OIG reports. Additional convictions of Medicaid and other convictions are not included. In the first half of 1997, there were 341 Medicaid convictions. 
Inpatient Prospective Payment System

- Consecutive inpatient stays

- Payments to acute-care hospitals operating under the Medicare prospective payment system

- Expansion of DRG payment window

Other payment issues

- Payment Error Prevention Program

- Periodic interim payments

- Payments for medical education

- Implementation of the Medicare program for critical-access hospitals

Miscellaneous issues

- Hospital privileging activities

- Peer review organizations' sanction authority

- Reporting of restraint and seclusion in psychiatric hospitals

\section{Procedural Coding System}

Current Procedural Terminology ${ }^{\circledR}$ (CPT), developed and updated by the American Medical Association (AMA), is the most commonly used coding system in the United States. CPT provides descriptive terms, guidelines, and identifies codes for reporting medical services and procedures. The first edition of CPT was published in 1966. CPT nomenclature for interventional procedures was non-specific and inadequate until 2000. Since then, sophisticated developments have taken place in interventional pain management coding with approval of many new codes. Consequently, there are now specific codes for facet joint nerve blocks, interlaminar epidural steroid injections, transforaminal epidural steroid injections, adhesiolysis, spinal endoscopic adhesiolysis, codes for multiple sympathetic and somatic nerve blocks, vertebroplasty, and refill and maintenance codes for implantables (80-85). The 2005 interventional pain management codes are as follows:

CPT

20526 Injection, therapeutic (eg, local anesthetic; corticosteroid), carpal tunnel

20550 tendon sheath, ligament injection

20551 Injection(s); single tendon origin/ insertion

20552 Injection(s); single or multiple trigger point(s), one or two muscle(s)

20553 Injection(s); single or multiple trigger point(s), three or more muscle(s)

20600 Arthrocentesis, aspiration and/or injection; small joint or bursa

20605 Arthrocentesis, aspiration and/or injection; intermediate joint or bursa

20610 Major Joint Injection

22520 Vertebroplasty (Thoracic)

22521 Vertebroplasty (Lumbar)

27093 Injection procedure for hip arthrography

27096 Injection procedure for sacroiliac joint

62263 Percutaneous lysis of epidural adhesions; 2 or more days

62264 Percutaneous lysis of epidural adhesions; 1 day

62270 Spinal puncture, lumbar, diagnostic

62272 Spinal puncture, therapeutic, for drainage of CSF

62273 Injection, epidural, of blood or clot patch

62280 Injection/infusion of neurolytic substance; subarachnoid

62281 Injection/infusion of neurolytic substance; epidural, cervical or thoracic

62282 Injection/infusion of neurolytic substance; epidural, lumbar, sacral (caudal)

62284 Myelography

62287 Aspiration or decompression procedure, percutaneous

62290 Injection procedure for diskography, each level; lumbar

62291 Injection procedure for diskography, each level; cervical or thoracic

62292 Injection procedure for chemonucleolysis; lumbar

62310 Injection, single, epidural or subarachnoid, cervical or thoracic

62311 Injection, single, epidural or subarachnoid, lumbar, sacral (caudal)

62318 Injection, including catheter placement, epidural or subarachnoid, cervical or thoracic

62319 Injection, including catheter placement, epidural or subarachnoid, lumbar, sacral (caudal)

62350 Implantation, reservoir/infusion pump

62355 Removal of previously implanted intrathecal or epidural catheter

62360 Implantation or replacement of device; subcutaneous reservoir

62361 Implantation or replacement of device; non-programmable pump

62362 Implantation or replacement of device; programmable pump

62365 Removal of subcutaneous reser- voir or pump, previously implanted

63650 Percutaneous implantation of neurostimulator electrode

63660 Revision or removal of spinal neurostimulator

63685 Insertion or replacement of spinal neurostimulator

63688 Revision or removal of implanted spinal neurostimulator

64400 Injection, anesthetic agent, trigeminal nerve

64402 Injection, anesthetic agent, facial nerve

64405 Injection, anesthetic agent, greater occipital nerve

64408 Injection, anesthetic agent, vagus nerve

64410 Injection, anesthetic agent, phrenic nerve

64412 Injection, anesthetic agent, spinal accessory nerve

64413 Injection, anesthetic agent, cervical plexus nerve

64415 Injection, anesthetic agent, brachial plexus nerve

64416 Injection, anesthetic agent, brachial plexus, continuous infusion by catheter

64417 Injection, anesthetic agent, axillary nerve

64418 Injection, anesthetic agent, suprascapular nerve

64420 Injection, anesthetic agent, intercostal nerve, single

64421 Injection, anesthetic agent, intercostal nerves, multiple

64425 Injection, anesthetic agent, ilioinguinal, iliohypogastric nerves

64445 Injection, anesthetic agent, sciatic nerve, single

64446 Injection, anesthetic agent, sciatic nerve, continuous infusion

64447 Injection, anesthetic agent, femoral nerve, single

64448 Injection, anesthetic agent, femoral nerve, continuous infusion

64449 Injection, anesthetic agent, lumbar plexus

64450 Injection, anesthetic agent, other peripheral nerve or branch

64470 Injection, anesthetic agent and/or steroid, cervical or thoracic, single

64472 Injection, anesthetic agent and/or steroid, cervical or thoracic, each additional level

64475 Injection, anesthetic agent and/or steroid, lumbar or sacral, single

64476 Injection, anesthetic agent and/or steroid, lumbar or sacral, each ad- 
ditional level

64479 Injection, anesthetic agent and/or steroid, transforaminal epidural, cervical or thoracic, single

64480 Injection, anesthetic agent and/ or steroid, transforaminal epidural, cervical or thoracic, each additional level

64483 Injection, anesthetic agent and/or steroid, transforaminal epidural, lumbar or sacral, single

64484 Injection, anesthetic agent and/or steroid, transforaminal epidural, lumbar or sacral, each additional level

64505 Injection, anesthetic agent, sphenopalatine ganglion

64508 Injection, anesthetic agent, carotid sinus

64510 Injection, anesthetic agent, stellate ganglion

64517 Injection, anesthetic agent, superior hypogastric plexus

64520 Injection, anesthetic agent, lumbar or thoracic

64530 Injection, anesthetic agent, celiac plexus

64600 Destruction by neurolytic agent, trigeminal nerve

64610 Destruction by neurolytic agent, trigeminal nerve second and third division, under radiologic monitoring

64612 Chemodenervation of muscles; muscle(s) innervated by facial nerve

64613 Chemodenervation of muscles; cervical spinal muscles

64614 Chemodenervation of muscles; extremity and/or trunk muscles

64620 Destruction by neurolytic agent; intercostal nerve

64622 Destruction by neurolytic agent; lumbar or sacral, single level

64623 Destruction by neurolytic agent; lumbar or sacral, each additional level

64626 Destruction by neurolytic agent; cervical or thoracic, single level

64627 Destruction by neurolytic agent; cervical or thoracic, each additional leve

64630 Destruction by neurolytic agent; pudendal nerve

64640 Destruction by neurolytic agent; other peripheral nerve or branch

64680 Destruction by neurolytic agent; celiac plexus

64681 Destruction by neurolytic agent; superior hypogastric plexus
72265 Contrast $x$-ray, lower spine

72270 Contrast $x$-ray of spine

72275 Epidurography

72285 Diskography C/T Radiological supervision and interpretation

72295 Diskography lumbar radiological supervision and interpretation

73525 Radiological examination

73542 Radiological examination, Sacroiliac joint arthrography, radiological

76000 Fluoroscopic examination

76001 Fluoroscopic, physician time more than one hour

76003 Fluoroscopic guidance for needle placement

76005 Fluoroscopic guidance and localization of needle or catheter tip for spine or therapeutic injection procedure

76012 Radiologic supervision and interpretation, percutaneous vertebroplasty, per vertebral body; under fluoroscopic guidance

76013 Radiologic supervision and interpretation, percutaneous vertebroplasty, per vertebral body; under CT guidance

95990 Refilling and maintenance of implantable pump or reservoir for drug delivery, spinal (intrathecal, epidural) or brain (intraventricular)

95991 Refilling and maintenance of implantable pump or reservoir for drug delivery, spinal (intrathecal, epidural) or brain (intraventricular); administered by physician

0027T Endoscopic lysis of epidural adhesions

0062T Percutaneous intradiscal annuloplasty, any method, unilateral; or bilateral including fluoroscopic guidance; single level

0063T One or more additional levels (List separately in addition to $0062 \mathrm{~T}$ for primary procedure)

\section{Correct Coding}

The National Correct Coding Council (NCCC) was created by the Healthcare Financing Administration, based on the Omnibus Budget Reconciliation Act. The NCCC initiated the National Correct Coding Committee to develop strategies to control improper coding, leading to inappropriate or increased payments in Part B claims $(86,87)$. Consequently, the $\mathrm{Na}$ tional Correct Coding policy was established in 1996 and eventually implement- ed the Medicare Correct Coding initiative to identify and isolate inappropriate coding, unbundling, and other irregularities in coding. Several versions of the National Correct Coding policies have been released in the form of the National Correct Coding Manuals starting with versions 5.0 up to the most recent publication 10.3 in October 2004 (88).

Correct coding essentially means reporting a group of procedures with an appropriate comprehensive code. Thus, it is essential that the coding description accurately describes what actually transpires at each patient encounter. A multitude of codes reflect the wide spectrum of services provided by various medical providers. Indeed, many medical services can be rendered by different methods and combinations of various procedures. Hence, multiple codes describing similar services are frequently necessary to accurately reflect the particular service a physician performs. However, when multiple procedures are performed at the same session, the procedure and post-procedure work do not have to be repeated for each procedure, and, therefore, a comprehensive code describing the multiple services commonly performed together can be used (86-88)

Many activities, which are integral to a procedure are considered as generic activities and are assumed to be included as acceptable medical/surgical practice and while they could be performed separately, they should not be considered as such when a code narrative is defined. Thus, all services integral to accomplishing a procedure will be considered to be included in that procedure and, therefore, will be considered a component and part of the comprehensive code.

\section{UTILIZATION OF INTERVENTIONAL TECHNIQUES}

Interventional techniques are performed by physicians in multiple specialties. However, the frequency with which these procedures are performed depends on the nature of the procedures performed. A great proportion of procedures such as trigger point injections or ligament injections are performed by rheumatologists, orthopedic surgeons, podiatrists, internists, and family practitioners; whereas intraarticular injections of various joints are performed by orthopedic surgeons, internists, and family practitioners; and the other majority of other 
interventional procedures which include epidurals, facet joint blocks, neurolytic procedures, and other nerve blocks are often performed by pain physicians. Officially, pain medicine or interventional pain management as a recognized subspecialty by the American Board of Medical Specialties includes anesthesiology, physical medicine and rehabilitation, and neurology and psychiatry. Others considered as interventional pain physicians more frequently are neurosurgeons, and orthopedic surgeons. Separate designations for interventional pain management (-09) and pain management or pain medicine (-72) went into effect in 2003 and 2002. Thus, any specific data in these categories (-09 and -72$)$ is mostly retrospective and preliminary at the present time.

For the purposes of this manuscript, official interventional pain physicians were considered to be anesthesiologists, physiatrists, neurologists, and psychiatrists along with all the physicians who had an interventional pain management or pain management designation. Extended interventional physicians included neurosurgeons and orthopedic surgeons, in addition to the official interventional pain physicians. Interventional radiologists who perform these procedures are not included in official or extended pain management, as they usually perform these procedures for diagnostic purposes rather than for management of chronic pain, except for vertebroplasty, which is a new procedure.

Interventional techniques are performed in multiple settings. Traditionally, the majority of interventional techniques were performed in the hospital outpatient departments (HOPDs). Evolution of in- terventional pain management as a distinct specialty, assisted other venues to offer these services, which include ambulatory surgical centers and physician offices. Thus, facility settings include HOPDs and ASCs, whereas non-facility settings include physician offices and all other settings. In 2000, CMS published a physician fee schedule, which included significantly higher payments for procedures performed in an office (also known as facility differential) to cover office overhead. This evaluation of frequency of interventional procedures identified the location as facility (HOPD or ASC) or non-facility.

Table 3 illustrates the differences in the performance of ligament and trigger point injections, intraarticular injections, facet joint interventions, epidurals, transforaminals, and intrathecal implantables by physicians in various specialties

Table 3. Frequency of utilization of trigger point and ligament injections, intraarticular injections, interlaminar epidurals (excluding continuous epidurals), transforaminal epidurals, facet joint interventions and implantables by various specialties for 2003, in Medicare recipients

\begin{tabular}{|c|c|c|c|c|c|c|}
\hline Specialty & $\begin{array}{l}\text { Trigger point } \\
\text { \& ligament } \\
\text { injections }\end{array}$ & $\begin{array}{l}\text { Intraarticular } \\
\text { injections }\end{array}$ & $\begin{array}{l}\text { Interlaminar } \\
\text { epidurals }\end{array}$ & $\begin{array}{c}\text { Transforaminal } \\
\text { epidurals }\end{array}$ & $\begin{array}{c}\text { Facet joint } \\
\text { interventions }\end{array}$ & Implantable \\
\hline Anesthesiology & $85,148(43 \%)$ & $47,886(34 \%)$ & $616,601(82 \%)$ & $180,642(69 \%)$ & $369,024(65 \%)$ & $10,008(100 \%)$ \\
\hline Physical medicine rehabilitation & $82,346(6 \%)$ & $85,722(9 \%)$ & $64,131(58 \%)$ & $70,839(65 \%)$ & $71,278(51 \%)$ & $418(100 \%)$ \\
\hline Neurology & $28,022(4 \%)$ & $6,272(4 \%)$ & $14,926(35 \%)$ & $16,453(15 \%)$ & $30,687(17 \%)$ & $110(100 \%)$ \\
\hline Psychiatry & $1,145(2 \%)$ & $826(8 \%)$ & $1,240(86 \%)$ & $1,999(87 \%)$ & $814(51 \%)$ & o \\
\hline Interventional Pain Management & $4,043(27 \%)$ & $3,920(28 \%)$ & $22,318(61 \%)$ & $17,219(52 \%)$ & $37,882(60 \%)$ & $1,084(100 \%)$ \\
\hline Pain management & $25,494(24 \%)$ & $15,965(18 \%)$ & $105,831(67 \%)$ & $54,422(64 \%)$ & $114,290(58 \%)$ & $3,441(100 \%)$ \\
\hline Neurosurgery & $6,388(2 \%)$ & $952(12 \%)$ & $10,885(70 \%)$ & $3,809(40 \%)$ & $12,129(62 \%)$ & $6,088(100 \%)$ \\
\hline Orthopedic surgery & $215,543(2 \%)$ & $2,362,432(3 \%)$ & $37,746(39 \%)$ & $15,100(62 \%)$ & $29,177(51 \%)$ & $1,518(100 \%)$ \\
\hline Interventional radiology & $16(63 \%)$ & $1,038(93 \%)$ & $2,353(87 \%)$ & $682(96 \%)$ & $1,082(83 \%)$ & 0 \\
\hline Rheumatology & $113,480(2 \%)$ & $632,951(4 \%)$ & $2,759(16 \%)$ & $1,360(9 \%)$ & $20,666(1 \%)$ & o \\
\hline Osteopathic manipulative therapy & $3,920(0 \%)$ & $3,945(2 \%)$ & $978(44 \%)$ & $274(19 \%)$ & $4,433(9 \%)$ & $3(100 \%)$ \\
\hline CRNA & $373(91 \%)$ & $40(95 \%)$ & $15,044(95 \%)$ & $415(85 \%)$ & $529(95 \%)$ & $239(100 \%)$ \\
\hline Diagnostic radiology & $315(31 \%)$ & $21,404(74 \%)$ & $32,543(62 \%)$ & $15,23(66 \%)$ & $15,700(72 \%)$ & $15(100 \%)$ \\
\hline Emergency medicine & $5,335(16 \%)$ & $21,837(55 \%)$ & $3,375(86 \%)$ & 1,452 (98\%) & $2,829(75 \%)$ & $95(100 \%)$ \\
\hline Family practice & $132,719(2 \%)$ & $416,433(4 \%)$ & $5,724(57 \%)$ & $3,959(43 \%)$ & $11,237(8 \%)$ & $23(100 \%)$ \\
\hline General Practice & $27,502(1 \%)$ & $75,462(3 \%)$ & $3,271(59 \%)$ & $2,871(37 \%)$ & $11,547(20 \%)$ & $111(100 \%)$ \\
\hline Internal medicine & $91,504(2 \%)$ & $430,590(4 \%)$ & $5,245(14 \%)$ & $3,966(34 \%)$ & $14,782(16 \%)$ & $121(100 \%)$ \\
\hline General surgery & $7,355(7 \%)$ & $19,796(4 \%)$ & $1,203(61 \%)$ & $1,111(75 \%)$ & $1,627(63 \%)$ & $794(100 \%)$ \\
\hline Nurse Practitioner & $14,721(3 \%)$ & $20,057(6 \%)$ & $273(72 \%)$ & $497(93 \%)$ & $1,068(51 \%)$ & $47(100 \%)$ \\
\hline Others & $348,289(2 \%)$ & $406,143(3 \%)$ & $2,195(48 \%)$ & $1,884(54 \%)$ & $4,390(30 \%)$ & $594(100 \%)$ \\
\hline Total & $1,193,658(6 \%)$ & $4,573,671(5 \%)$ & $948,641(74 \%)$ & $394,188(63 \%)$ & $755,171(55 \%)$ & $24,709(100 \%)$ \\
\hline
\end{tabular}

Source: Utilization data By Specialty from CMS (ref. 89)

() shows percentage of procedures utilized in facility settings (HOPD or ASC)

Trigger point \& ligament injections - 20550, 20551, 20552, 20553; Intraarticular injections - 20600, 20605, 20610; Interlaminar epidurals - 62310, 62311

Transforaminal $-64479,64480,64483,64484$; Facet joint interventions - 64470/2, 64475/6, 64622/3, 64226/7; Implantable pumps \& Stimulators - 6236o/1, $62362,63650 / 5,63660,63685 / 8$ 
Table 4. Summary of frequency of utilizations of various categories of interventional procedures (excluding continuous epidurals, implantables, disc procedures, intraarticular injections, trigger point and ligament injections) in Medicare population from 1998-2003

\begin{tabular}{|l|c|c|c|c|c|c|}
\hline & $\mathbf{1 9 9 8}$ & $\mathbf{1 9 9 9}$ & $\mathbf{2 0 0 0}$ & $\mathbf{2 0 0 1}$ & $\mathbf{2 0 0 2}$ & $\mathbf{2 0 0 3}$ \\
\hline $\begin{array}{l}\text { Epidural, spinal neurolysis, and } \\
\text { adhesiolysis procedures }\end{array}$ & $\begin{array}{c}802,735 \\
(76 \%)\end{array}$ & $\begin{array}{c}803,078 \\
(74 \%)\end{array}$ & $\begin{array}{c}860,787 \\
(79 \%)\end{array}$ & $\begin{array}{c}1,013,552 \\
(78 \%)\end{array}$ & $\begin{array}{c}1,199,324 \\
(74 \%)\end{array}$ & $\begin{array}{c}1,370,862 \\
(71 \%)\end{array}$ \\
\hline $\begin{array}{l}\text { Facet joint interventions and } \\
\text { SI joint blocks }\end{array}$ & $\begin{array}{c}274,130 \\
(73 \%)\end{array}$ & $\begin{array}{c}304,564 \\
(72 \%)\end{array}$ & $\begin{array}{c}424,796 \\
(67 \%)\end{array}$ & $\begin{array}{c}543,509 \\
(62 \%)\end{array}$ & $\begin{array}{c}708,186 \\
(58 \%)\end{array}$ & $\begin{array}{c}884,035 \\
(53 \%)\end{array}$ \\
\hline Other types of nerve blocks & $\begin{array}{c}329,552 \\
(33 \%)\end{array}$ & $313,415(33 \%)$ & $\begin{array}{c}324,320 \\
(35 \%)\end{array}$ & $\begin{array}{c}343,277 \\
(35 \%)\end{array}$ & $\begin{array}{c}457,219 \\
(30 \%)\end{array}$ & $\begin{array}{c}490,337 \\
(28 \%)\end{array}$ \\
\hline Total & $\begin{array}{c}\mathbf{1 , 4 0 6 , 4 1 7} \\
(\mathbf{6 5 \% )}\end{array}$ & $\begin{array}{c}\mathbf{1 , 4 2 1 , 0 5 7} \\
(\mathbf{6 4 \% )}\end{array}$ & $\begin{array}{c}\mathbf{1 , 6 0 9 , 9 0 3} \\
(\mathbf{6} \%)\end{array}$ & $\begin{array}{c}\mathbf{1 , 9 0 0 , 3 3 8} \\
(\mathbf{6 6 \% )}\end{array}$ & $\begin{array}{c}\mathbf{2 , 3 6 4 , 7 2 9} \\
(\mathbf{6 1 \% )}\end{array}$ & $\begin{array}{c}\mathbf{2 , 7 4 5 , 2 3 4} \\
(\mathbf{5 8} \%)\end{array}$ \\
\hline
\end{tabular}

Source: Utilization data by Specialty from CMS (ref. 89)

() shows percentage of procedures utilized in facility settings (HOPD and ASC)

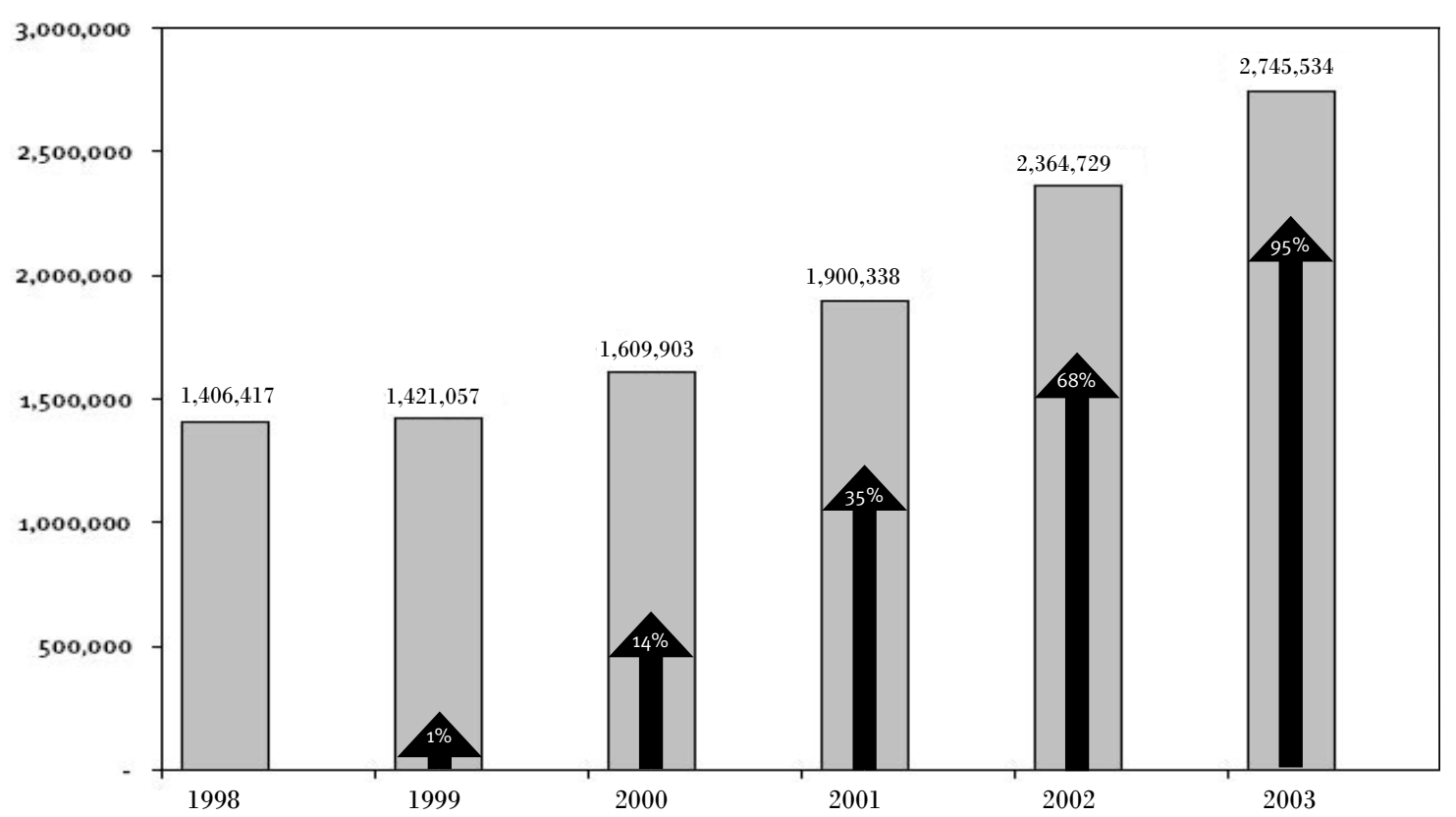

Fig. 3. Increasing utilization of epidural, spinal neurolysis, and adhesiolysis procedures; facet joint interventions and SI joint blocks; and other types of nerve blocks ((excluding continuous epidurals, implantables, disc procedures, intraarticular injections, trigger point and ligament injections) from 1998 to 2003 (ref. 89)

(89). As illustrated, of a total of $1,193,658$ trigger point and ligament injections, the majority were performed by primary care specialties, podiatrists, orthopedic surgeons, rheumatologists, followed by anesthesiologists and physiatrists. Official pain management physicians performed approximately 19\% (226,198 of $1,193,658)$ of all the procedures in this category. Orthopedic surgeons performed $18 \%$ of all the ligament and trigger point injections. In contrast, the majority of intraarticular injections $(52 \%$ or $2,362,432$ ) were performed by orthopedic surgeons. Pain physicians performed only a small proportion $(3 \%)$ of intraarticular injections. In 2003, 948,641 interlaminar epidural injections, excluding continuous infusions, were performed in the Medicare population. In addition, 394,188 transforaminal epidurals were also performed, with a combined total of $1,342,829$ epidural injections in 2003 for chronic pain management. Pain physicians performed the majority of epidurals, facet joint interventions and implantables.

Table 4 illustrates the frequency of utilization of multiple interventional techniques excluding implantables, disc procedures, continuous epidurals, intraarticular injections, trigger point and ligament injections from 1998 to 2003.
These numbers also illustrate increasing proportion of non-facility procedures, from $35 \%$ in 1998 to $42 \%$ in 2003 (89). Fig. 3 illustrates the growth of these procedures with a $95 \%$ increase in utilization from 1998 to 2003 . The presentation in Figs. 4 and 5 shows a trend with approximately $50 \%$ of the procedures being performed by non-interventional physicians in an office setting. These illustrations show that in the category of other nerve blocks, the procedures performed by official pain physicians declined to $50 \%$ in 2003 while the proportion by extended pain management declined to $52 \%$ in 2003 in Medicare recipients. 


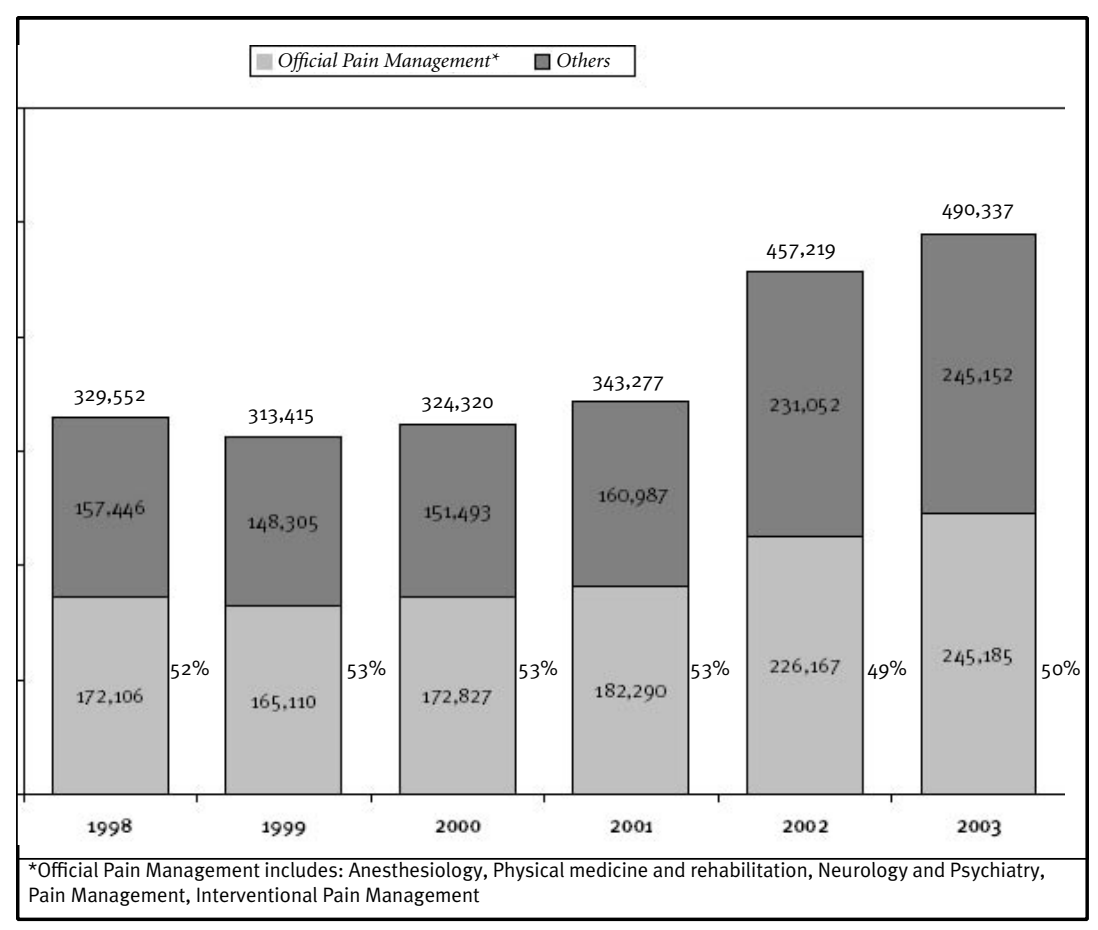

Fig. 4. Comparison of frequency of utilization of various nerve blocks excluding epidurals, disc injections, and facet joint blocks in Medicare recipients from 1998-2003 (ref. 89)

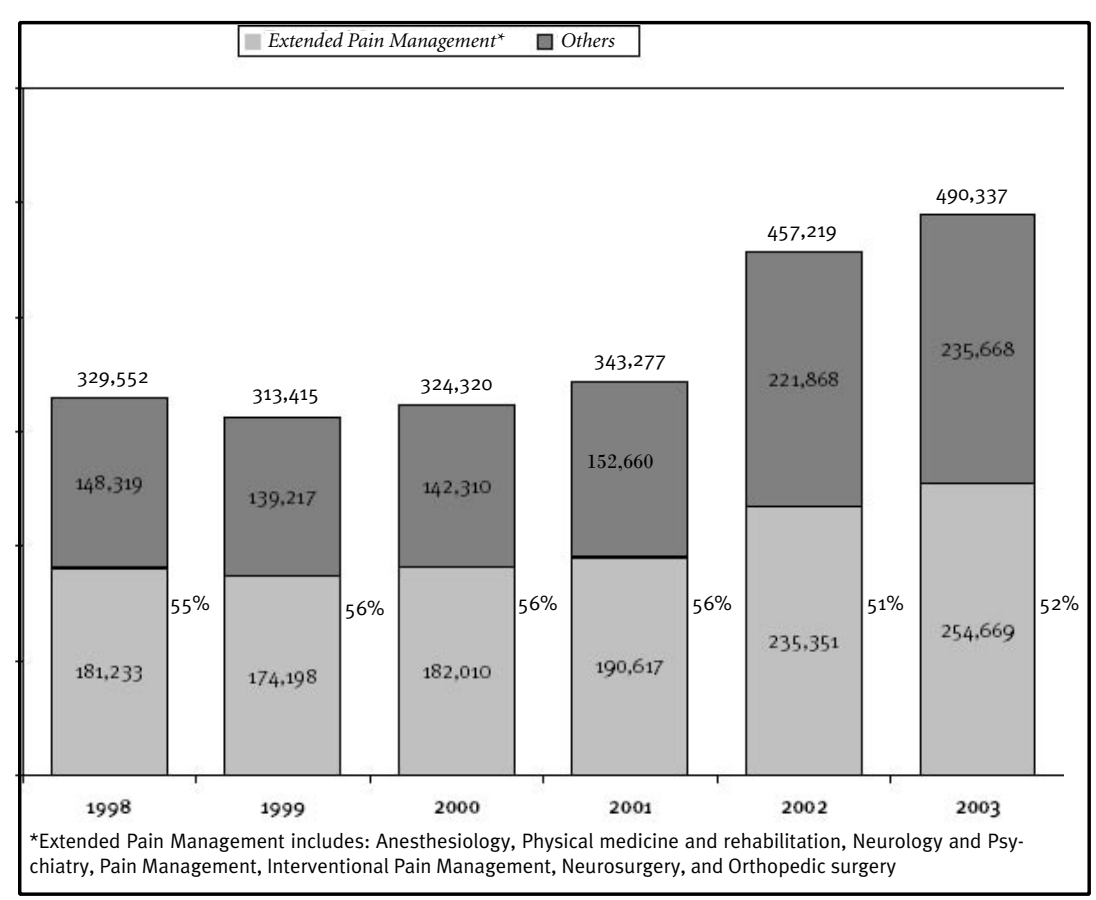

Fig. 5. Comparison of frequency of utilization of various nerve blocks excluding epidurals, disc injections, and facet joint blocks in Medicare recipients from 1998-2003 (ref. 89)

Table 5 illustrates the number of facet various specialties (89). Table 6 illustrates joint interventions and sacroiliac joint in- statistics for these procedures from 1998 jections in Medicare recipients in 2003, by to 2003 with increasing frequency (89).
Fig. 6 shows an overall increase of $222 \%$ from 1998 to 2003. Fig. 7 shows official pain management specialties and others performing the procedures with increasing frequency. The number of facet joint interventions and sacroiliac joint blocks performed by other physicians have increased from 64,858 in 1998 to 147,127 in 2003 in Medicare recipients (Fig. 7). The proportion of procedures performed in facility settings also has decreased from $73 \%$ in 1998 to $53 \%$ in 2003 .

The next category of interventional techniques for discussion includes the the most commonly performed procedures, including interlaminar epidurals, transforaminal epidurals, spinal neurolysis, and adhesiolysis procedures. In this analysis, we have excluded continuous epidurals, either in the cervical spine or in the lumbar spine, as these are most commonly performed for postoperative anesthetic purposes, rather than chronic pain management. Table 3 illustrates the frequency of utilization by various specialties of the epidural procedures for 2003 (89). In contrast, Table 7 illustrates overall increase of utilization of these procedures from 1998 to 2003 (89). As shown in Table 7, epidural interventions have increased by $71 \%$ from 1998 to 2003 in Medicare recipients to approximately 1.4 million from 802,735. Inappropriate coding may be identified for transforaminal epidurals, specifically cervical transforaminal epidurals, as the majority are performed outside facility settings. Fig. 8 illustrates distribution of procedures among pain physicians and others. The majority of interlaminar and transforaminal epidurals (87\%) were performed by pain physicians. Even then, $13 \%$ of epidurals were performed by other physicians. In addition, $26 \%$ of interlaminar epidurals and $57 \%$ of transforaminal epidurals are performed in office settings. Performance of transforaminals by primary care physicians, nurse practitioners, nurse anesthetists, physician assistants, rheumatologists, etc., specifically in an office setting, may indicate performing these procedures without fluoroscopic guidance, which is considered as inappropriate.

The majority of implantables, $61 \%$ of 24,709 in Medicare population in 2003, were performed by pain physicians, $25 \%$ by neurosurgeons, $6 \%$ by orthopedic surgeons, and $8 \%$ by all other specialists. As shown in Table 3, there is significant variability among the specialists performing 
Table 5. Frequency of utilization of Facet joint interventions and sacroiliac joint blocks by various specialties for 2003, in Medicare recipients

\begin{tabular}{|c|c|c|c|c|c|c|c|c|c|c|}
\hline \multirow[b]{2}{*}{ Specialty } & \multirow{2}{*}{$\begin{array}{c}\begin{array}{c}\text { Sacroiliac } \\
\text { Joint } \\
\text { Injection }\end{array} \\
27096 \\
\end{array}$} & \multirow{2}{*}{$\begin{array}{c}\text { Cervical } \\
\text { Facet } \\
\text { Joint } \\
\text { Blocks }\end{array}$} & \multirow{2}{*}{$\begin{array}{c}\text { Thoracic } \\
\text { Facet } \\
\text { Joint } \\
\text { Blocks } \\
64472 \\
\end{array}$} & \multicolumn{2}{|c|}{$\begin{array}{c}\text { Lumbar Facet Joint } \\
\text { Blocks }\end{array}$} & \multicolumn{2}{|c|}{$\begin{array}{l}\text { Lumbar Facet } \\
\text { Neurolysis }\end{array}$} & \multicolumn{2}{|c|}{$\begin{array}{l}\text { Cervical/Thoracic } \\
\text { Facet Neurolysis }\end{array}$} & \multirow[b]{2}{*}{ Total } \\
\hline & & & & 64475 & 64476 & 64622 & 64623 & 64626 & 64627 & \\
\hline Anesthesiology & $\begin{array}{r}71,969 \\
(48 \%) \\
\end{array}$ & $\begin{array}{c}17,798 \\
(57 \%) \\
\end{array}$ & $\begin{array}{c}37,122 \\
(55 \%) \\
\end{array}$ & $\begin{array}{c}77,363 \\
(66 \%) \\
\end{array}$ & $\begin{array}{c}155,037 \\
(62 \%) \\
\end{array}$ & $\begin{array}{l}19,830 \\
(76 \%) \\
\end{array}$ & $\begin{array}{c}48,749 \\
(73 \%) \\
\end{array}$ & $\begin{array}{l}3,934 \\
(75 \%) \\
\end{array}$ & $\begin{array}{l}9,191 \\
(71 \%) \\
\end{array}$ & $\begin{array}{c}440,993 \\
(62 \%) \\
\end{array}$ \\
\hline Neurology & $\begin{array}{l}4,248 \\
(12 \%)\end{array}$ & $\begin{array}{l}4,121 \\
(10 \%)\end{array}$ & $\begin{array}{l}4,319 \\
(13 \%)\end{array}$ & $\begin{array}{l}8,606 \\
(16 \%)\end{array}$ & $\begin{array}{c}10,902 \\
(18 \%)\end{array}$ & $\begin{array}{c}838 \\
(27 \%)\end{array}$ & $\begin{array}{l}1,402 \\
(41 \%)\end{array}$ & $\begin{array}{c}188 \\
(23 \%)\end{array}$ & $\begin{array}{c}311 \\
(39 \%)\end{array}$ & $\begin{array}{c}34,935 \\
(17 \%)\end{array}$ \\
\hline $\begin{array}{l}\text { Physical medicine } \\
\text { rehabilitation }\end{array}$ & $\begin{array}{l}14,990 \\
(35 \%) \\
\end{array}$ & $\begin{array}{l}5,054 \\
(35 \%)\end{array}$ & $\begin{array}{l}6,242 \\
(49 \%)\end{array}$ & $\begin{array}{l}21,310 \\
(46 \%) \\
\end{array}$ & $\begin{array}{c}28,212 \\
(51 \%) \\
\end{array}$ & $\begin{array}{l}2,840 \\
(71 \%) \\
\end{array}$ & $\begin{array}{l}6,032 \\
(72 \%) \\
\end{array}$ & $\begin{array}{c}533 \\
(75 \%) \\
\end{array}$ & $\begin{array}{l}1,055 \\
(76 \%) \\
\end{array}$ & $\begin{array}{c}86,268 \\
(49 \%)\end{array}$ \\
\hline Psychiatry & $\begin{array}{c}161 \\
(43 \%) \\
\end{array}$ & $\begin{array}{c}80 \\
(66 \%) \\
\end{array}$ & $\begin{array}{c}49 \\
(90 \%) \\
\end{array}$ & $\begin{array}{c}275 \\
(55 \%) \\
\end{array}$ & $\begin{array}{c}282 \\
(54 \%) \\
\end{array}$ & $\begin{array}{c}52 \\
(6 \%) \\
\end{array}$ & $\begin{array}{c}71 \\
(14 \%) \\
\end{array}$ & $\begin{array}{c}3 \\
(100 \%) \\
\end{array}$ & $\begin{array}{c}2 \\
(100 \%) \\
\end{array}$ & $\begin{array}{c}975 \\
(50 \%) \\
\end{array}$ \\
\hline Pain management & $\begin{array}{c}16,236 \\
(41 \%)\end{array}$ & $\begin{array}{l}6,074 \\
(57 \%) \\
\end{array}$ & $\begin{array}{l}11,612 \\
(56 \%) \\
\end{array}$ & $\begin{array}{r}23,817 \\
(57 \%) \\
\end{array}$ & $\begin{array}{c}46,572 \\
(54 \%) \\
\end{array}$ & $\begin{array}{l}6,427 \\
(69 \%) \\
\end{array}$ & $\begin{array}{c}15,842 \\
(65 \%)\end{array}$ & $\begin{array}{l}1,229 \\
(71 \%) \\
\end{array}$ & $\begin{array}{l}2,717 \\
(70 \%)\end{array}$ & $\begin{array}{c}130,526 \\
(56 \%)\end{array}$ \\
\hline $\begin{array}{l}\text { Interventional Pain } \\
\text { Management }\end{array}$ & $\begin{array}{l}5,329 \\
(36 \%)\end{array}$ & $\begin{array}{l}3,077 \\
(65 \%)\end{array}$ & $\begin{array}{l}4,877 \\
(64 \%)\end{array}$ & $\begin{array}{l}7,375 \\
(56 \%)\end{array}$ & $\begin{array}{l}13,797 \\
(56 \%)\end{array}$ & $\begin{array}{l}2,018 \\
(63 \%)\end{array}$ & $\begin{array}{l}4,983 \\
(66 \%)\end{array}$ & $\begin{array}{c}541 \\
(57 \%)\end{array}$ & $\begin{array}{l}1,214 \\
(65 \%)\end{array}$ & $\begin{array}{l}43,211 \\
(57 \%)\end{array}$ \\
\hline CRNA & $\begin{array}{c}69 \\
(100 \%) \\
\end{array}$ & $\begin{array}{c}32 \\
(81 \%) \\
\end{array}$ & $\begin{array}{c}16 \\
(88 \%) \\
\end{array}$ & $\begin{array}{c}188 \\
(90 \%) \\
\end{array}$ & $\begin{array}{c}181 \\
(100 \%) \\
\end{array}$ & $\begin{array}{c}39 \\
(100 \%) \\
\end{array}$ & $\begin{array}{c}50 \\
(100 \%) \\
\end{array}$ & $\begin{array}{c}11 \\
(100 \%) \\
\end{array}$ & $\begin{array}{c}12 \\
(100 \%) \\
\end{array}$ & $\begin{array}{c}598 \\
(95 \%) \\
\end{array}$ \\
\hline Diagnostic radiology & $\begin{array}{l}2,796 \\
(67 \%)\end{array}$ & $\begin{array}{l}1,031 \\
(71 \%)\end{array}$ & $\begin{array}{c}689 \\
(66 \%)\end{array}$ & $\begin{array}{l}7,741 \\
(74 \%)\end{array}$ & $\begin{array}{l}5,523 \\
(72 \%)\end{array}$ & $\begin{array}{c}235 \\
(54 \%)\end{array}$ & $\begin{array}{c}367 \\
(57 \%)\end{array}$ & $\begin{array}{c}43 \\
(47 \%)\end{array}$ & $\begin{array}{c}71 \\
(46 \%)\end{array}$ & $\begin{array}{c}18,496 \\
(71 \%)\end{array}$ \\
\hline Emergency medicine & $\begin{array}{c}323 \\
(70 \%) \\
\end{array}$ & $\begin{array}{c}317 \\
(36 \%) \\
\end{array}$ & $\begin{array}{c}436 \\
(56 \%) \\
\end{array}$ & $\begin{array}{c}568 \\
(69 \%) \\
\end{array}$ & $\begin{array}{c}952 \\
(86 \%) \\
\end{array}$ & $\begin{array}{c}148 \\
(96 \%) \\
\end{array}$ & $\begin{array}{c}318 \\
(100 \%) \\
\end{array}$ & $\begin{array}{c}30 \\
(97 \%) \\
\end{array}$ & $\begin{array}{c}60 \\
(93 \%) \\
\end{array}$ & $\begin{array}{l}3,152 \\
(74 \%) \\
\end{array}$ \\
\hline Family practice & $\begin{array}{l}1,963 \\
(9 \%) \\
\end{array}$ & $\begin{array}{l}1,285 \\
(4 \%) \\
\end{array}$ & $\begin{array}{l}1,081 \\
(4 \%)\end{array}$ & $\begin{array}{c}4,041 \\
(8 \%) \\
\end{array}$ & $\begin{array}{l}3,459 \\
(10 \%) \\
\end{array}$ & $\begin{array}{l}502 \\
(6 \%) \\
\end{array}$ & $\begin{array}{l}751 \\
(6 \%) \\
\end{array}$ & $\begin{array}{c}55 \\
(22 \%) \\
\end{array}$ & $\begin{array}{c}63 \\
(13 \%) \\
\end{array}$ & $\begin{array}{c}13,200 \\
(8 \%) \\
\end{array}$ \\
\hline General Practice & $\begin{array}{c}589 \\
(31 \%) \\
\end{array}$ & $\begin{array}{c}1,027 \\
(9 \%)\end{array}$ & $\begin{array}{c}589 \\
(32 \%) \\
\end{array}$ & $\begin{array}{c}5,122 \\
(9 \%)\end{array}$ & $\begin{array}{l}3,987 \\
(22 \%) \\
\end{array}$ & $\begin{array}{c}331 \\
(86 \%)\end{array}$ & $\begin{array}{c}424 \\
(77 \%) \\
\end{array}$ & $\begin{array}{c}25 \\
(64 \%) \\
\end{array}$ & $\begin{array}{c}42 \\
(60 \%) \\
\end{array}$ & $\begin{array}{l}12,136 \\
(20 \%)\end{array}$ \\
\hline General surgery & $\begin{array}{c}221 \\
(75 \%) \\
\end{array}$ & $\begin{array}{c}86 \\
(28 \%) \\
\end{array}$ & $\begin{array}{c}86 \\
(56 \%) \\
\end{array}$ & $\begin{array}{c}465 \\
(42 \%) \\
\end{array}$ & $\begin{array}{c}469 \\
(56 \%) \\
\end{array}$ & $\begin{array}{c}206 \\
(90 \%) \\
\end{array}$ & $\begin{array}{c}281 \\
(96 \%) \\
\end{array}$ & $\begin{array}{c}9 \\
(67 \%) \\
\end{array}$ & $\begin{array}{c}25 \\
(100 \%) \\
\end{array}$ & $\begin{array}{l}1,848 \\
(64 \%) \\
\end{array}$ \\
\hline Internal medicine & $\begin{array}{l}2229 \\
(7 \%) \\
\end{array}$ & $\begin{array}{c}1,695 \\
(9 \%) \\
\end{array}$ & $\begin{array}{l}1,190 \\
(21 \%) \\
\end{array}$ & $\begin{array}{c}5,962 \\
(9 \%)\end{array}$ & $\begin{array}{l}3,728 \\
(23 \%) \\
\end{array}$ & $\begin{array}{c}709 \\
(21 \%) \\
\end{array}$ & $\begin{array}{l}1,380 \\
(25 \%) \\
\end{array}$ & $\begin{array}{c}43 \\
(51 \%) \\
\end{array}$ & $\begin{array}{c}75 \\
(47 \%) \\
\end{array}$ & $\begin{array}{l}17,011 \\
(15 \%) \\
\end{array}$ \\
\hline $\begin{array}{l}\text { Interventional } \\
\text { radiology }\end{array}$ & $\begin{array}{c}224 \\
(91 \%) \\
\end{array}$ & $\begin{array}{c}110 \\
(78 \%) \\
\end{array}$ & $\begin{array}{c}47 \\
(81 \%) \\
\end{array}$ & $\begin{array}{c}503 \\
(85 \%) \\
\end{array}$ & $\begin{array}{c}397 \\
(87 \%) \\
\end{array}$ & $\begin{array}{c}8 \\
(50 \%) \\
\end{array}$ & $\begin{array}{c}9 \\
(0 \%) \\
\end{array}$ & $\begin{array}{c}3 \\
(0 \%) \\
\end{array}$ & $\begin{array}{c}5 \\
(0 \%) \\
\end{array}$ & $\begin{array}{l}1,306 \\
(85 \%) \\
\end{array}$ \\
\hline Neurosurgery & $\begin{array}{l}1,454 \\
(33 \%) \\
\end{array}$ & $\begin{array}{c}952 \\
(49 \%) \\
\end{array}$ & $\begin{array}{l}1,303 \\
(63 \%) \\
\end{array}$ & $\begin{array}{l}3,220 \\
(57 \%) \\
\end{array}$ & $\begin{array}{l}4,701 \\
(71 \%) \\
\end{array}$ & $\begin{array}{c}467 \\
(58 \%) \\
\end{array}$ & $\begin{array}{l}1,105 \\
(58 \%) \\
\end{array}$ & $\begin{array}{c}115 \\
(36 \%) \\
\end{array}$ & $\begin{array}{c}266 \\
(27 \%) \\
\end{array}$ & $\begin{array}{l}13,583 \\
(59 \%) \\
\end{array}$ \\
\hline Nurse Practitioner & $\begin{array}{c}177 \\
(66 \%) \\
\end{array}$ & $\begin{array}{c}60 \\
(45 \%) \\
\end{array}$ & $\begin{array}{c}118 \\
(42 \%) \\
\end{array}$ & $\begin{array}{c}507 \\
(40 \%) \\
\end{array}$ & $\begin{array}{c}300 \\
(71 \%) \\
\end{array}$ & $\begin{array}{c}25 \\
(60 \%) \\
\end{array}$ & $\begin{array}{c}46 \\
(59 \%) \\
\end{array}$ & $\begin{array}{c}4 \\
(100 \%) \\
\end{array}$ & $\begin{array}{c}8 \\
(100 \%) \\
\end{array}$ & $\begin{array}{l}1,245 \\
(53 \%) \\
\end{array}$ \\
\hline Orthopedic surgery & $\begin{array}{l}4,250 \\
(34 \%) \\
\end{array}$ & $\begin{array}{l}1,607 \\
(30 \%) \\
\end{array}$ & $\begin{array}{l}1,160 \\
(48 \%) \\
\end{array}$ & $\begin{array}{c}12,088 \\
(40 \%)\end{array}$ & $\begin{array}{c}12,695 \\
(59 \%) \\
\end{array}$ & $\begin{array}{c}477 \\
(81 \%) \\
\end{array}$ & $\begin{array}{c}968 \\
(90 \%) \\
\end{array}$ & $\begin{array}{c}72 \\
(74 \%) \\
\end{array}$ & $\begin{array}{c}110 \\
(83 \%) \\
\end{array}$ & $\begin{array}{l}33,427 \\
(49 \%) \\
\end{array}$ \\
\hline $\begin{array}{l}\text { Osteopathic } \\
\text { manipulative therapy }\end{array}$ & $\begin{array}{c}161 \\
(14 \%) \\
\end{array}$ & $\begin{array}{c}210 \\
(10 \%)\end{array}$ & $\begin{array}{c}613 \\
(6 \%) \\
\end{array}$ & $\begin{array}{l}790 \\
(9 \%) \\
\end{array}$ & $\begin{array}{c}2,665 \\
(5 \%)\end{array}$ & $\begin{array}{c}33 \\
(91 \%)\end{array}$ & $\begin{array}{c}69 \\
(96 \%)\end{array}$ & $\begin{array}{c}14 \\
(86 \%) \\
\end{array}$ & $\begin{array}{c}39 \\
(90 \%)\end{array}$ & $\begin{array}{l}4,594 \\
(9 \%)\end{array}$ \\
\hline Rheumatology & $\begin{array}{l}595 \\
(4 \%) \\
\end{array}$ & $\begin{array}{c}4,899 \\
(0 \%) \\
\end{array}$ & $\begin{array}{l}3,190 \\
(0 \%)\end{array}$ & $\begin{array}{c}8,087 \\
(1 \%) \\
\end{array}$ & $\begin{array}{c}4,467 \\
(1 \%) \\
\end{array}$ & $\begin{array}{c}11 \\
(18 \%) \\
\end{array}$ & $\begin{array}{c}10 \\
(20 \%) \\
\end{array}$ & $\begin{array}{c}1 \\
(100 \%) \\
\end{array}$ & $\begin{array}{c}1 \\
(100 \%) \\
\end{array}$ & $\begin{array}{c}21,261 \\
(1 \%) \\
\end{array}$ \\
\hline Others & $\begin{array}{c}880 \\
(31 \%)\end{array}$ & $\begin{array}{c}443 \\
(17 \%)\end{array}$ & $\begin{array}{c}750 \\
(42 \%)\end{array}$ & $\begin{array}{l}1,235 \\
(19 \%)\end{array}$ & $\begin{array}{l}1,476 \\
(22 \%)\end{array}$ & $\begin{array}{c}119 \\
(62 \%)\end{array}$ & $\begin{array}{c}309 \\
(86 \%)\end{array}$ & $\begin{array}{c}24 \\
(50 \%)\end{array}$ & $\begin{array}{c}34 \\
(62 \%)\end{array}$ & $\begin{array}{l}5,270 \\
(30 \%)\end{array}$ \\
\hline Total & $\begin{array}{c}128,864 \\
(42 \%)\end{array}$ & $\begin{array}{c}49,958 \\
(40 \%)\end{array}$ & $\begin{array}{c}75,489 \\
(49 \%)\end{array}$ & $\begin{array}{c}189,263 \\
(51 \%)\end{array}$ & $\begin{array}{c}299,802 \\
(55 \%)\end{array}$ & $\begin{array}{l}35,315 \\
(70 \%)\end{array}$ & $\begin{array}{l}83,166 \\
(69 \%)\end{array}$ & $\begin{array}{l}6,877 \\
(70 \%)\end{array}$ & $\begin{array}{l}15,301 \\
(69 \%)\end{array}$ & $\begin{array}{c}884,035 \\
(53 \%)\end{array}$ \\
\hline
\end{tabular}

Source: Utilization data By Specialty from CMS (ref. 89)

() shows percentage of procedures utilized in facility settings (HOPD and ASC)

implantables. Further, Table 8 illustrates to 2002, and 30\% from 2002 to 2003, with ous specialties in the year 2003. Fig. 9 in the growth of implantables, since 1998. an overall growth of $100 \%$ from 1998 to contrast, shows the frequency of discograThe growth ranged from 3\% between 2003 in the Medicare population. phy procedures from 1998 to 2003 , with 1998 and $1999,8 \%$ from 1999 to 2000 , Table 9 illustrates the distribution an increase of 120\% (89). As illustrated, $23 \%$ from 2000 to $2001,13 \%$ from 2001 of discography procedures among vari- the majority of these procedures are per- 
Table 6. Comparison of frequency of utilization of Facet joint interventions and sacroiliac joint blocks in Medicare recipients from 1998-2003

\begin{tabular}{|c|c|c|c|c|c|c|c|}
\hline CPT & Code Description & 1998 & 1999 & 2000 & 2001 & 2002 & 2003 \\
\hline 27096 & Sacroiliac joint blocks & $\begin{array}{l}2,374 \\
(86 \%)\end{array}$ & $\begin{array}{l}2,281 \\
(81 \%)\end{array}$ & $\begin{array}{c}49,554 \\
(59 \%)\end{array}$ & $\begin{array}{c}85,664 \\
(51 \%)\end{array}$ & $\begin{array}{c}101,749 \\
(48 \%)\end{array}$ & $\begin{array}{c}128,864 \\
(42 \%)\end{array}$ \\
\hline 64470 & $\mathrm{C} / \mathrm{T}$ facet joint block - single & $\begin{array}{l}6,286 \\
(65 \%) \\
\end{array}$ & $\begin{array}{l}6,438 \\
(65 \%) \\
\end{array}$ & $\begin{array}{l}24,751 \\
(48 \%) \\
\end{array}$ & $\begin{array}{l}34,500 \\
(43 \%) \\
\end{array}$ & $\begin{array}{l}41,935 \\
(44 \%) \\
\end{array}$ & $\begin{array}{l}49,958 \\
(40 \%)\end{array}$ \\
\hline 64472 & $\begin{array}{l}\mathrm{C} / \mathrm{T} \text { facet joint block } \\
\text { - additional }\end{array}$ & $\begin{array}{c}349 \\
(90 \%)\end{array}$ & $\begin{array}{c}574 \\
(82 \%)\end{array}$ & $\begin{array}{c}33,573 \\
(62 \%)\end{array}$ & $\begin{array}{c}47,684 \\
(55 \%)\end{array}$ & $\begin{array}{l}61,981 \\
(53 \%)\end{array}$ & $\begin{array}{c}75,489 \\
(49 \%)\end{array}$ \\
\hline 64475 & L/S facet joint block - single & $\begin{array}{l}84,854 \\
(64 \%) \\
\end{array}$ & $\begin{array}{l}87,395 \\
(65 \%)\end{array}$ & $\begin{array}{c}101,539 \\
(61 \%)\end{array}$ & $\begin{array}{c}121,234 \\
(59 \%)\end{array}$ & $\begin{array}{c}155,620 \\
(55 \%)\end{array}$ & $\begin{array}{c}189,263 \\
(51 \%)\end{array}$ \\
\hline 64476 & L/S facet joint block add. & $\begin{array}{c}145,267 \\
(75 \%) \\
\end{array}$ & $\begin{array}{c}163,170 \\
(73 \%) \\
\end{array}$ & $\begin{array}{c}153,252 \\
(71 \%) \\
\end{array}$ & $\begin{array}{c}175,854 \\
(67 \%) \\
\end{array}$ & $\begin{array}{c}240,243 \\
(61 \%) \\
\end{array}$ & $\begin{array}{c}299,802 \\
(55 \%)\end{array}$ \\
\hline 64622 & L/S facet neurolysis - single & $\begin{array}{l}10,371 \\
(84 \%) \\
\end{array}$ & $\begin{array}{c}13,079 \\
(80 \%) \\
\end{array}$ & $\begin{array}{l}15,117 \\
(84 \%) \\
\end{array}$ & $\begin{array}{c}18,792 \\
(79 \%) \\
\end{array}$ & $\begin{array}{c}25,744 \\
(77 \%) \\
\end{array}$ & $\begin{array}{l}35,315 \\
(70 \%) \\
\end{array}$ \\
\hline 64623 & $\begin{array}{l}\text { L/S facet neurolysis } \\
\text { - additional }\end{array}$ & $\begin{array}{c}24,255 \\
(88 \%)\end{array}$ & $\begin{array}{l}31,018 \\
(85 \%) \\
\end{array}$ & $\begin{array}{c}38,206 \\
(88 \%) \\
\end{array}$ & $\begin{array}{c}47,632 \\
(81 \%) \\
\end{array}$ & $\begin{array}{c}63,522 \\
(76 \%) \\
\end{array}$ & $\begin{array}{l}83,166 \\
(69 \%) \\
\end{array}$ \\
\hline 64626 & $\mathrm{C} / \mathrm{T}$ facet neurolysis - single & $\begin{array}{c}25 \\
(100 \%) \\
\end{array}$ & $\begin{array}{c}35 \\
(100 \%) \\
\end{array}$ & $\begin{array}{l}2,750 \\
(83 \%) \\
\end{array}$ & $\begin{array}{l}3,815 \\
(77 \%) \\
\end{array}$ & $\begin{array}{l}5,190 \\
(76 \%) \\
\end{array}$ & $\begin{array}{l}6,877 \\
(70 \%) \\
\end{array}$ \\
\hline 64627 & $\begin{array}{l}\mathrm{C} / \mathrm{T} \text { facet neurolysis } \\
\text { - additional }\end{array}$ & $\begin{array}{c}349 \\
(90 \%)\end{array}$ & $\begin{array}{c}574 \\
(82 \%) \\
\end{array}$ & $\begin{array}{l}6,054 \\
(87 \%) \\
\end{array}$ & $\begin{array}{l}8,334 \\
(77 \%) \\
\end{array}$ & $\begin{array}{r}12,202 \\
(73 \%) \\
\end{array}$ & $\begin{array}{l}15,301 \\
(69 \%) \\
\end{array}$ \\
\hline \multicolumn{2}{|l|}{ Total } & $\begin{array}{c}274,130 \\
(73 \%)\end{array}$ & $\begin{array}{c}304,564 \\
(72 \%)\end{array}$ & $\begin{array}{c}424,796 \\
(67 \%)\end{array}$ & $\begin{array}{c}543,509 \\
(62 \%)\end{array}$ & $\begin{array}{c}708,186 \\
(58 \%)\end{array}$ & $\begin{array}{c}884,035 \\
(53 \%)\end{array}$ \\
\hline
\end{tabular}

Source: Utilization data By Specialty from CMS (ref. 89)

() shows percentage of procedures utilized in facility settings (HOPD and ASC)

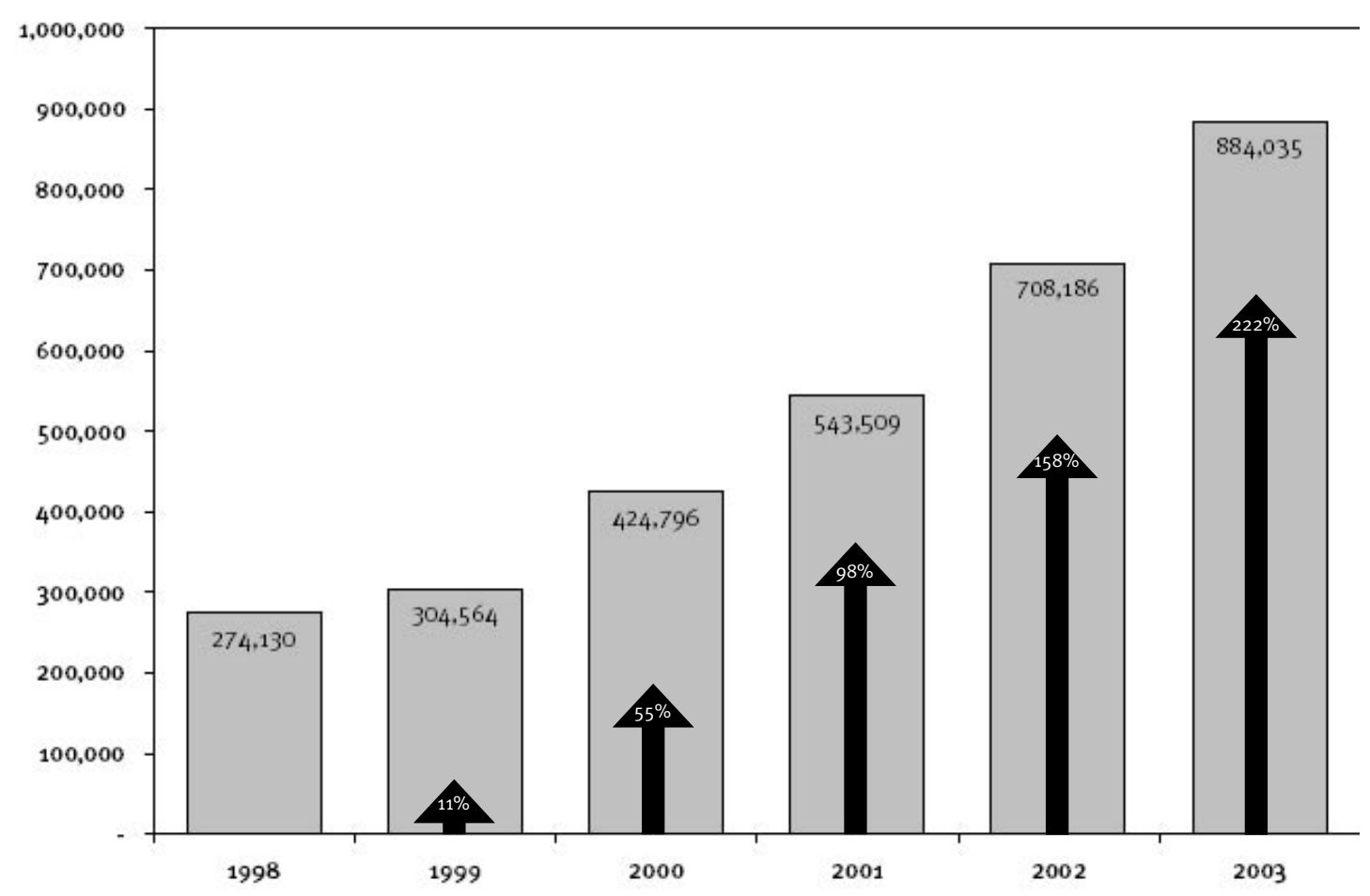

Fig. 6. Increasing utilization of facet joint interventions and sacroiliac joint blocks from 1998 to 2003 (ref. 89) 


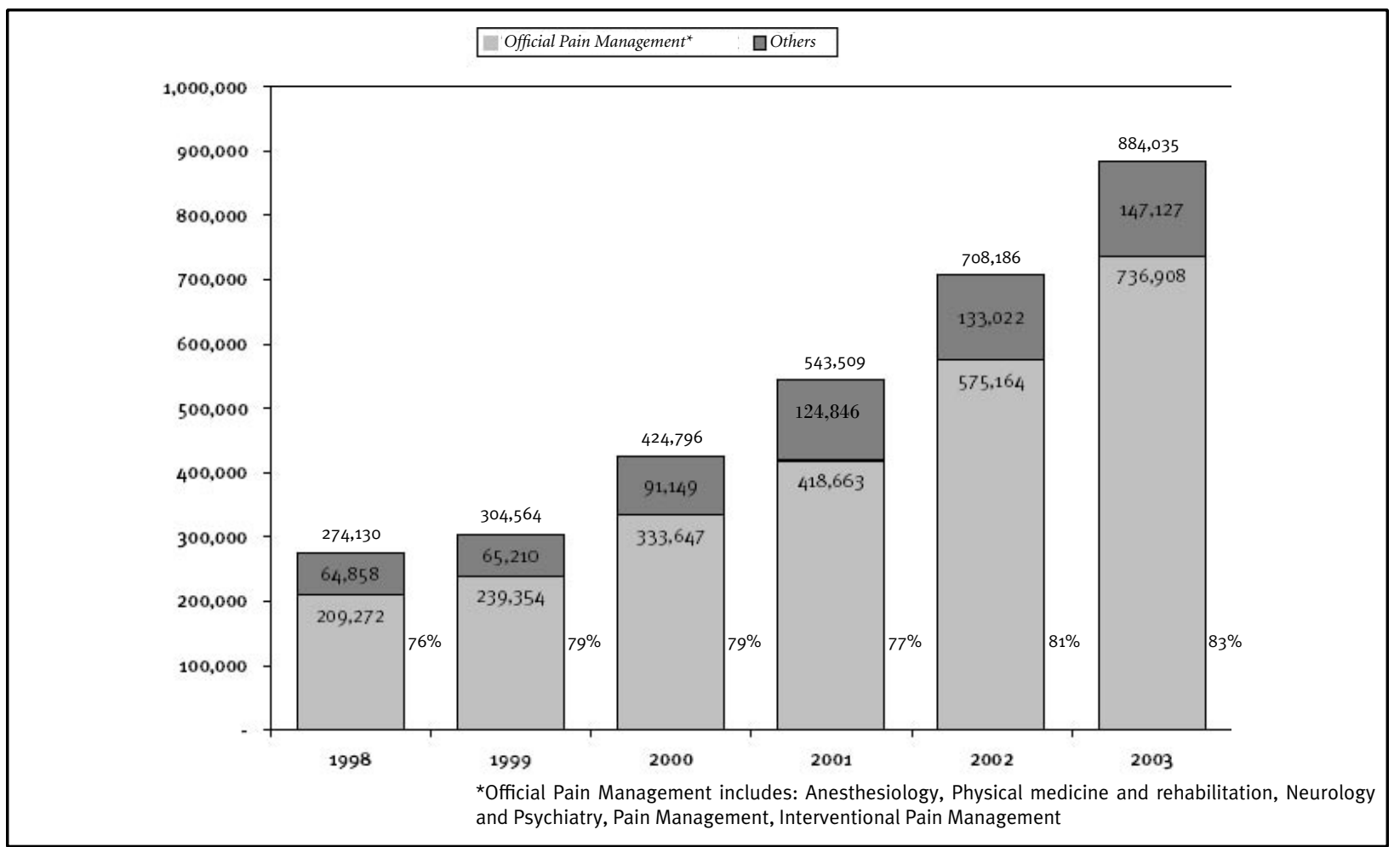

Fig. 7. Comparison of frequency of utilization of Facet joint interventions and sacroiliac joint blocks in Medicare recipients from 1998-2003 (ref. 89)

Table 7. Comparison of frequency of utilization of various types epidural, spinal neurolysis, and adhesiolysis procedures in Medicare recipients from 1998-2003

\begin{tabular}{|c|c|c|c|c|c|c|c|}
\hline HCPCS & Description & 1998 & 1999 & 2000 & 2001 & 2002 & 2003 \\
\hline 62263 & $\begin{array}{l}\text { Epidural lysis of adhesions }-2 \text { or } 3 \\
\text { days }\end{array}$ & $\begin{array}{l}1,001 \\
(88 \%)\end{array}$ & $\begin{array}{l}1,558 \\
(80 \%)\end{array}$ & $\begin{array}{l}8,778 \\
(91 \%)\end{array}$ & $\begin{array}{l}10,463 \\
(88 \%)\end{array}$ & $\begin{array}{l}14,430 \\
(83 \%)\end{array}$ & $\begin{array}{l}7,183 \\
(83 \%)\end{array}$ \\
\hline 62264 & Epidural lysis of adhesions - 1day & - & - & - & - & $\begin{array}{c}724 \\
(84 \%) \\
\end{array}$ & $\begin{array}{l}9,733 \\
(79 \%) \\
\end{array}$ \\
\hline 62280 & Subarachnoid neurolysis & $\begin{array}{c}226 \\
(91 \%)\end{array}$ & $\begin{array}{c}233 \\
(68 \%) \\
\end{array}$ & $\begin{array}{c}197 \\
(89 \%) \\
\end{array}$ & $\begin{array}{c}242 \\
(89 \%) \\
\end{array}$ & $\begin{array}{c}225 \\
(100 \%)\end{array}$ & $\begin{array}{c}233 \\
(78 \%) \\
\end{array}$ \\
\hline 62281 & Cervical epidural neurolysis & $\begin{array}{l}1,719 \\
(80 \%) \\
\end{array}$ & $\begin{array}{l}1,569 \\
(72 \%) \\
\end{array}$ & $\begin{array}{l}1,199 \\
(83 \%) \\
\end{array}$ & $\begin{array}{l}1,320 \\
(73 \%) \\
\end{array}$ & $\begin{array}{l}1,305 \\
(68 \%) \\
\end{array}$ & $\begin{array}{l}1,233 \\
(59 \%) \\
\end{array}$ \\
\hline 62282 & Lumbar epidural neurolysis & $\begin{array}{l}9,543 \\
(58 \%) \\
\end{array}$ & $\begin{array}{c}10,883 \\
(51 \%) \\
\end{array}$ & $\begin{array}{l}11,139 \\
(48 \%) \\
\end{array}$ & $\begin{array}{l}11,990 \\
(55 \%) \\
\end{array}$ & $\begin{array}{c}10,392 \\
(58 \%) \\
\end{array}$ & $\begin{array}{l}9,651 \\
(49 \%) \\
\end{array}$ \\
\hline 62310 & Cervical/Thoracic epidural & $\begin{array}{c}64,563 \\
(86 \%) \\
\end{array}$ & $\begin{array}{l}69,381 \\
(81 \%)\end{array}$ & $\begin{array}{l}75,741 \\
(83 \%)\end{array}$ & $\begin{array}{c}84,385 \\
(80 \%)\end{array}$ & $\begin{array}{l}99,117 \\
(76 \%)\end{array}$ & $\begin{array}{c}109,783 \\
(73 \%)\end{array}$ \\
\hline 62311 & Lumbar/Sacral epidural & $\begin{array}{c}608,453 \\
(85 \%) \\
\end{array}$ & $\begin{array}{c}619,543 \\
(80 \%) \\
\end{array}$ & $\begin{array}{c}618,362 \\
(83 \%) \\
\end{array}$ & $\begin{array}{c}702,713 \\
(81 \%) \\
\end{array}$ & $\begin{array}{c}786,919 \\
(77 \%)\end{array}$ & $\begin{array}{c}838,858 \\
(74 \%) \\
\end{array}$ \\
\hline 64479 & C/T Transforaminal epidural - single & $\begin{array}{l}3,292 \\
(34 \%) \\
\end{array}$ & $\begin{array}{l}3,213 \\
(32 \%) \\
\end{array}$ & $\begin{array}{c}13,454 \\
(52 \%) \\
\end{array}$ & $\begin{array}{c}14,732 \\
(52 \%) \\
\end{array}$ & $\begin{array}{c}18,583 \\
(50 \%) \\
\end{array}$ & $\begin{array}{r}21,882 \\
(48 \%)\end{array}$ \\
\hline 64480 & $\begin{array}{l}\mathrm{C} / \mathrm{T} \text { Transforaminal epidural-each } \\
\text { additional }\end{array}$ & $\begin{array}{c}17,066 \\
(22 \%)\end{array}$ & $\begin{array}{l}12,931 \\
(26 \%)\end{array}$ & $\begin{array}{l}9,434 \\
(60 \%)\end{array}$ & $\begin{array}{l}8,537 \\
(47 \%) \\
\end{array}$ & $\begin{array}{l}10,835 \\
(39 \%)\end{array}$ & $\begin{array}{r}15,769 \\
(34 \%)\end{array}$ \\
\hline 64483 & L/S Transforaminal - single & $\begin{array}{l}45,385 \\
(34 \%) \\
\end{array}$ & $\begin{array}{l}44,751 \\
(32 \%)\end{array}$ & $\begin{array}{l}85,006 \\
(66 \%)\end{array}$ & $\begin{array}{c}125,534 \\
(72 \%) \\
\end{array}$ & $\begin{array}{c}177,679 \\
(70 \%)\end{array}$ & $\begin{array}{c}242,491 \\
(67 \%) \\
\end{array}$ \\
\hline 64484 & L/S Transforaminal - each additional & $\begin{array}{l}51,487 \\
(23 \%) \\
\end{array}$ & $\begin{array}{l}39,016 \\
(26 \%)\end{array}$ & $\begin{array}{l}37,477 \\
(63 \%) \\
\end{array}$ & $\begin{array}{c}53,133 \\
(69 \%) \\
\end{array}$ & $\begin{array}{l}7,9115 \\
(64 \%) \\
\end{array}$ & $\begin{array}{c}114,046 \\
(62 \%) \\
\end{array}$ \\
\hline \multicolumn{2}{|l|}{ Total } & $\begin{array}{c}802,735 \\
(76 \%)\end{array}$ & $\begin{array}{c}803,078 \\
(74 \%)\end{array}$ & $\begin{array}{c}860,787 \\
(79 \%)\end{array}$ & $\begin{array}{c}1,013,552 \\
(78 \%)\end{array}$ & $\begin{array}{c}1,199,324 \\
(74 \%)\end{array}$ & $\begin{array}{c}1,370,862 \\
(71 \%)\end{array}$ \\
\hline
\end{tabular}

Source: Utilization data By Specialty from CMS (ref. 89)

() shows percentage of procedures utilized in facility settings (HOPD and ASC) 


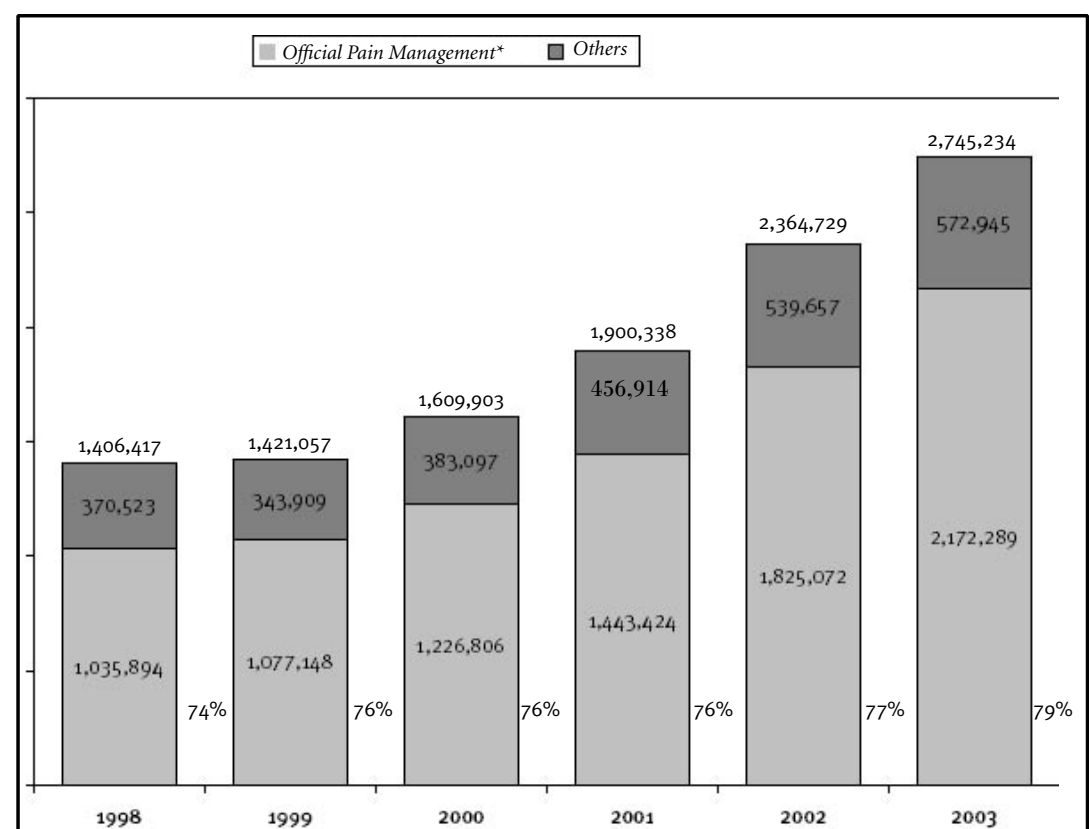

Fig. 8. Comparison of frequency of utilization of various epidural, spinal, and adhesiolysis, facet joint interventions and sacroiliac joint blocks, other types of nerve blocks (not included discography, implantable pumps and Stimulators) in Medicare recipients from 1998-2003 (ref. 89)

formed by official pain management physicians followed by diagnostic radiologists with some being performed by a number of physicians from other specialties.

Table 10 summarizes a multitude of peripheral nerve blocks and sympathetic blocks in Medicare recipients from 1998 to 2003 (89). This illustration excludes all types of epidurals, disc injections, implantables, intraarticular injections, trigger point injections, and facet joint interventions As shown in Figs. 4 and 5, most of these procedures were performed in an office setting. Figure 4 illustrates the comparative utilization of various types of nerve blocks, excluding all types of epidurals, disc injections, implantables, intraarticular joint injections, trigger point injections, and facet joint and sacroiliac joint interventions, with significant increases from 1998 through 2003. Figure 5 illustrates data for extended pain management physicians. The trend shows an increase by other physicians performing 148,319 procedures in 1998 in this category to 235,668 in 2003 . Finally, Figure 10 illustrates a declining proportion of procedures, from 2000 to 2003 performed in facility settings (89).

\section{DISCUSSION}

There is no doubt that the specialty of interventional pain management is facing growing pains. Increased utilization without appropriate documentation of medical necessity may lead to fraud and abuse investigations. It is also important for physicians to follow local medical review policies or local coverage decisions for all the procedures and stay within the limits of these recommendations, not only with regards to frequency, but for medical necessity purposes. Increased funding from Medicare Part B is limited to inflation and increased member enrollment. Consequently, increased utiliza-

Table 8. Comparison of frequency of utilization of implantable pumps and Stimulators in Medicare recipients from 1998-2003

\begin{tabular}{|c|c|c|c|c|c|c|}
\hline & 1998 & 1999 & 2000 & 2001 & 2002 & 2003 \\
\hline $\begin{array}{l}62360 \text { - Implantation or replacement } \\
\text { of device; subcutaneous reservoir }\end{array}$ & 944 & 1,113 & 602 & 743 & 618 & 738 \\
\hline $\begin{array}{l}62361 \text { - Implantation or replacement } \\
\text { of device; non-programmable pump }\end{array}$ & 108 & 367 & 373 & 298 & 213 & 184 \\
\hline $\begin{array}{l}62362 \text { - Implantation or replacement } \\
\text { of device; programmable pump }\end{array}$ & 3,414 & 3,739 & 4,625 & 5,241 & 5,557 & 5,486 \\
\hline $\begin{array}{l}63650 \text { - Percutaneous implantation } \\
\text { of neurostimulator electrode }\end{array}$ & 3,397 & 3,008 & 3,443 & 4,746 & 5,715 & 8,549 \\
\hline $\begin{array}{l}63655 \text {-Laminectomy for implantation } \\
\text { of neurostimulator electrodes }\end{array}$ & 465 & 440 & 531 & 758 & 922 & 1,482 \\
\hline $\begin{array}{l}63660-\text { Revision or removal of spinal } \\
\text { neurostimulator }\end{array}$ & 1,244 & 1,317 & 1,414 & 1,815 & 2,032 & 2,753 \\
\hline $\begin{array}{l}63685-\text { Insertion or replacement of } \\
\text { spinal neurostimulator }\end{array}$ & 1,628 & 1,577 & 1,450 & 1,716 & 2,088 & 3,308 \\
\hline \multirow[t]{2}{*}{$\begin{array}{l}63688 \text { - Revision or removal of } \\
\text { implanted spinal neurostimulator }\end{array}$} & 1,176 & 1,133 & 1,297 & 1,523 & 1,803 & 2,209 \\
\hline & 12,376 & 12,694 & 13,735 & 16,840 & 18,948 & 24,709 \\
\hline Percent of growth from previous year & - & $3 \%$ & $8 \%$ & $23 \%$ & $13 \%$ & $30 \%$ \\
\hline
\end{tabular}

Source: Utilization data By Specialty from CMS (ref. 89) 


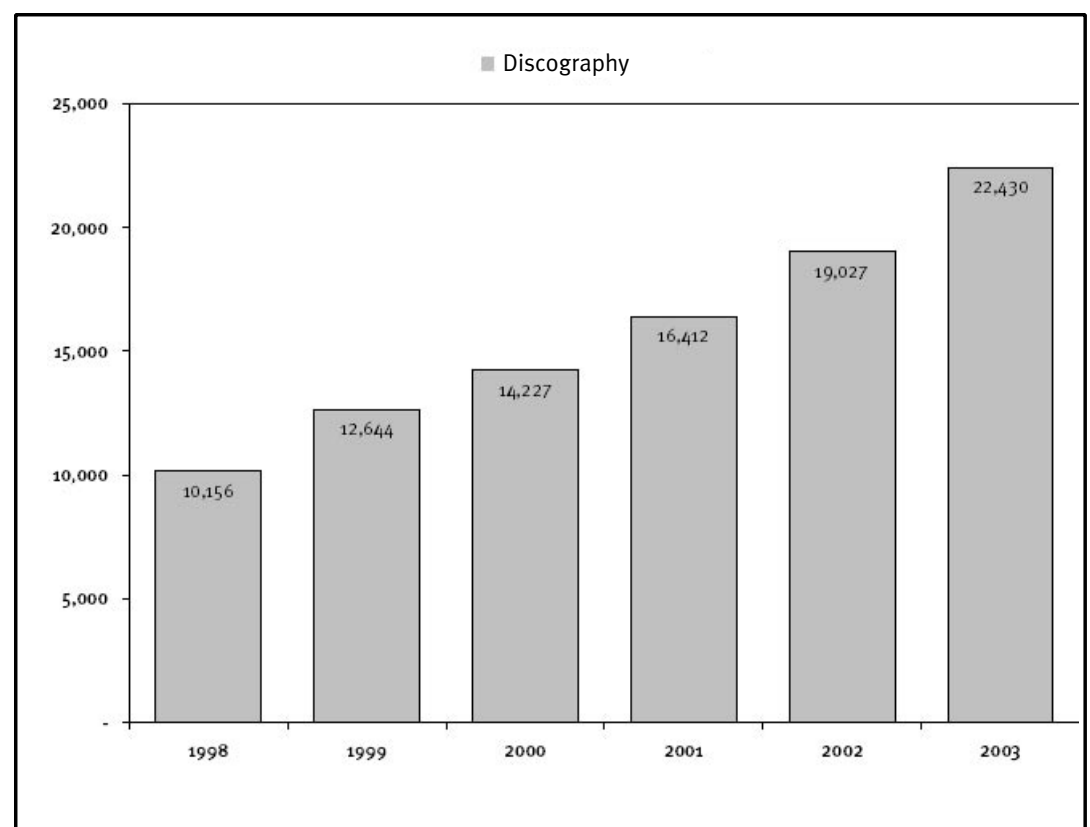

Fig. 9. Comparison of frequency of utilization of discography in Medicare recipients from 1998-2003

Source: Utilization data By Specialty from CMS (ref. 89)

() shows percentage of procedures utilized in facility settings (HOPD and ASC)

Table 9. Comparison of frequency of utilization of Discography in Medicare recipients in year 2003

\begin{tabular}{|l|l|l|l|}
\hline Specialty & $\begin{array}{l}\text { Lumbar } \\
\text { Discography } \\
\mathbf{( 6 2 2 9 0 )}\end{array}$ & $\begin{array}{l}\text { Cervical } \\
\text { Discography } \\
\mathbf{( 6 2 2 9 1 )}\end{array}$ & $\begin{array}{l}\text { Lub./Cer. } \\
\text { Discography } \\
\mathbf{( 6 2 2 9 0 , 6 2 9 9 1 )}\end{array}$ \\
\hline Anesthesiology & $7,169(70 \%)$ & $698(84 \%)$ & $7,867(71 \%)$ \\
\hline Neurology & $201(70 \%)$ & $44(100 \%)$ & $245(75 \%)$ \\
\hline Physical medicine rehabilitation & $1,717(83 \%)$ & $100(90 \%)$ & $1,817(83 \%)$ \\
\hline Psychiatry & $23(61 \%)$ & 0 & $23(61 \%)$ \\
\hline Pain management & $2,099(80 \%)$ & $235(88 \%)$ & $2,334(80 \%)$ \\
\hline Interventional Pain Management & $692(53 \%)$ & $113(67 \%)$ & $805(55 \%)$ \\
\hline Diagnostic radiology & $4,033(82 \%)$ & $467(73 \%)$ & $4,500(81 \%)$ \\
\hline Emergency medicine & $41(100 \%)$ & $13(77 \%)$ & $54(94 \%)$ \\
\hline Family practice & $183(26 \%)$ & $17(12 \%)$ & $200(25 \%)$ \\
\hline General Practice & $37(92 \%)$ & 0 & $37(92 \%)$ \\
\hline General surgery & $28(100 \%)$ & 0 & $28(100 \%)$ \\
\hline Internal medicine & $49(24 \%)$ & 0 & $49(24 \%)$ \\
\hline Interventional radiology & $453(93 \%)$ & $24(42 \%)$ & $477(90 \%)$ \\
\hline Neurosurgery & $712(82 \%)$ & $119(61 \%)$ & $831(79 \%)$ \\
\hline Nurse Practitioner & $3(100 \%)$ & 0 & $3(100 \%)$ \\
\hline Orthopedic surgery & $2,777(99 \%)$ & $217(99 \%)$ & $2,994(99 \%)$ \\
\hline Osteopathic manipulative therapy & $23(74 \%)$ & 0 & $23(74 \%)$ \\
\hline Others & $135(67 \%)$ & $8(13 \%)$ & $143(64 \%)$ \\
\hline Total & $\mathbf{2 0 , 3 7 5}(\mathbf{7 8} \%)$ & $\mathbf{2 , 0 5 5}(\mathbf{8 1} \%)$ & $\mathbf{2 2 , 4 3 0 ( 7 9 \% )}$ \\
\hline Sorce & & \\
\hline
\end{tabular}

Source: Utilization data By Specialty from CMS (ref. 89)

() shows percentage of procedures utilized in facility settings (HOPD and ASC) tion will reduce the fee for procedures, as the total amounts dispensable are limited (budget neutral or zero sum game).

Limitations of the discussions here are that statistics are only available on Medicare recipients. While substantial variations may exist with certain procedures, it is presumed that overall utilization of these procedures may be 3 to 5 times the total Medicare volume. It is conceivable that 12 to 15 million interventional procedures were performed in the United States last year. Thus, the statistics could become frightening for all involved in the care of patients.

To avoid any misconceptions regarding abuse in interventional pain management, with diagnostic and therapeutic interventional procedures, it is not sufficient to state that these are good procedures. Procedures should be performed in a disciplined manner meeting medical necessity criteria with appropriate, defensible and justifiable practice, using established algorithms and guidelines.

An algorithm indicates to practitioners how investigations might best be applied in a responsible and efficient manner. Further, an algorithm may serve to define poor or inappropriate practices. Algorithms and guidelines may be applied to precision diagnosis, therapeutic interventions and continued management. Algorithms promote efficiency by directing practitioners to the action that is more likely to be productive, but also help practitioners to reduce futile and nonproductive activities. Further, if the algorithmic approach is based on evidence-based medicine, it provides enormous value for patients, points out a thorough and deep understanding of the evidence, and assists the practitioner in making valid judgments about the best course of action. In fact, it is advisable to evaluate evidencebased medicine and clinical guidelines, which can result in superior, or even different patient management strategies.

It has been demonstrated that for acute low back pain, use of evidencebased medical care and usual care resulted in marginally better performance compared to usual care, in the short-term (90). However, in the long-term, evidence-based care achieved clinically and statistically significant gains, with fewer patients requiring continuing care and remaining in pain. In contrast, others (91) in evaluating the impact of guidelines on ordering of magnetic resonance imaging 
Table 10. Comparison of frequency of utilization of various types of nerve blocks excluding all types of epidurals, disc injections, implantables, intraarticular injections, trigger point injections and facet joint blocks in Medicare recipients for 1998-2003

\begin{tabular}{|c|c|c|c|c|c|c|c|}
\hline HCPCS & & 1998 & 1999 & 2000 & 2001 & 2002 & 2003 \\
\hline 64400 & Trigeminal N.B. & $\begin{array}{l}9,363 \\
(36 \%)\end{array}$ & $\begin{array}{l}7,402 \\
(26 \%) \\
\end{array}$ & $\begin{array}{l}7,173 \\
(28 \%) \\
\end{array}$ & $\begin{array}{l}6,749 \\
(37 \%) \\
\end{array}$ & $\begin{array}{l}7,341 \\
(36 \%) \\
\end{array}$ & $\begin{array}{l}8,199 \\
(36 \%)\end{array}$ \\
\hline 64402 & Facial N.B. & $\begin{array}{l}2,523 \\
(55 \%) \\
\end{array}$ & $\begin{array}{l}2,040 \\
(51 \%) \\
\end{array}$ & $\begin{array}{l}2,001 \\
(54 \%) \\
\end{array}$ & $\begin{array}{l}1,801 \\
(52 \%) \\
\end{array}$ & $\begin{array}{l}2,007 \\
(48 \%) \\
\end{array}$ & $\begin{array}{l}1,631 \\
(44 \%) \\
\end{array}$ \\
\hline 64405 & Greater occipital N.B. & $\begin{array}{c}25,305 \\
(37 \%) \\
\end{array}$ & $\begin{array}{c}24,826 \\
(33 \%)\end{array}$ & $\begin{array}{c}25,424 \\
(33 \%) \\
\end{array}$ & $\begin{array}{l}29,913 \\
(32 \%) \\
\end{array}$ & $\begin{array}{c}34,695 \\
(27 \%) \\
\end{array}$ & $\begin{array}{l}39,341 \\
(26 \%)\end{array}$ \\
\hline 64408 & Vagus N.B. & $\begin{array}{c}258 \\
(00 \%) \\
\end{array}$ & $\begin{array}{c}348 \\
(04 \%)\end{array}$ & $\begin{array}{c}478 \\
(03 \%)\end{array}$ & $\begin{array}{l}248 \\
(0 \%) \\
\end{array}$ & $\begin{array}{l}727 \\
(1 \%) \\
\end{array}$ & $\begin{array}{l}551 \\
(5 \%)\end{array}$ \\
\hline 64410 & Phrenic N.B. & $\begin{array}{c}35 \\
(100 \%) \\
\end{array}$ & $\begin{array}{c}67 \\
(81 \%) \\
\end{array}$ & $\begin{array}{c}26 \\
(100 \%) \\
\end{array}$ & $\begin{array}{c}30 \\
(100 \%) \\
\end{array}$ & $\begin{array}{c}27 \\
(100 \%) \\
\end{array}$ & $\begin{array}{c}56 \\
(70 \%) \\
\end{array}$ \\
\hline 64412 & Spinal accessory N.B. & $\begin{array}{l}1,170 \\
(28 \%) \\
\end{array}$ & $\begin{array}{l}1,436 \\
(14 \%) \\
\end{array}$ & $\begin{array}{l}1,261 \\
(14 \%) \\
\end{array}$ & $\begin{array}{l}1,482 \\
(14 \%) \\
\end{array}$ & $\begin{array}{l}1,418 \\
(18 \%) \\
\end{array}$ & $\begin{array}{c}1,386 \\
(8 \%) \\
\end{array}$ \\
\hline 64413 & Cervical plexus block & $\begin{array}{c}10,014 \\
(21 \%)\end{array}$ & $\begin{array}{l}6,963 \\
(32 \%) \\
\end{array}$ & $\begin{array}{l}5,738 \\
\text { (36\%) } \\
\end{array}$ & $\begin{array}{l}5,677 \\
\text { (38\%) }\end{array}$ & $\begin{array}{l}5,762 \\
(29 \%) \\
\end{array}$ & $\begin{array}{l}5,967 \\
(36 \%)\end{array}$ \\
\hline 64415 & Brachial plexus block & $\begin{array}{l}9,037 \\
(69 \%) \\
\end{array}$ & $\begin{array}{l}15,061 \\
(79 \%) \\
\end{array}$ & $\begin{array}{l}18,771 \\
(89 \%) \\
\end{array}$ & $\begin{array}{c}23,662 \\
(92 \%) \\
\end{array}$ & $\begin{array}{c}29,533 \\
(94 \%) \\
\end{array}$ & $\begin{array}{c}36,999 \\
(94 \%) \\
\end{array}$ \\
\hline 64417 & Axillary N.B. & $\begin{array}{l}1,750 \\
(66 \%) \\
\end{array}$ & $\begin{array}{l}1,834 \\
(73 \%) \\
\end{array}$ & $\begin{array}{l}2,002 \\
(84 \%) \\
\end{array}$ & $\begin{array}{l}2,225 \\
(90 \%) \\
\end{array}$ & $\begin{array}{l}2676 \\
(94 \%) \\
\end{array}$ & $\begin{array}{l}3203 \\
(91 \%) \\
\end{array}$ \\
\hline 64418 & Suprascapular N.B. & $\begin{array}{l}9,961 \\
(24 \%) \\
\end{array}$ & $\begin{array}{l}9,705 \\
(21 \%)\end{array}$ & $\begin{array}{c}10,657 \\
(21 \%) \\
\end{array}$ & $\begin{array}{c}12,365 \\
(16 \%) \\
\end{array}$ & $\begin{array}{c}10,837 \\
(18 \%) \\
\end{array}$ & $\begin{array}{c}13,382 \\
(17 \%) \\
\end{array}$ \\
\hline 64420 & Intercostal N.B single & $\begin{array}{l}7,936 \\
(43 \%) \\
\end{array}$ & $\begin{array}{l}7,138 \\
(39 \%) \\
\end{array}$ & $\begin{array}{l}8,058 \\
(45 \%) \\
\end{array}$ & $\begin{array}{l}7,839 \\
(40 \%) \\
\end{array}$ & $\begin{array}{l}6,209 \\
(36 \%) \\
\end{array}$ & $\begin{array}{l}5,463 \\
(39 \%) \\
\end{array}$ \\
\hline 64421 & Intercostal N. Blocks & $\begin{array}{c}19,485 \\
(66 \%) \\
\end{array}$ & $\begin{array}{l}18,311 \\
(59 \%) \\
\end{array}$ & $\begin{array}{c}16,645 \\
(66 \%) \\
\end{array}$ & $\begin{array}{c}16,509 \\
(66 \%) \\
\end{array}$ & $\begin{array}{c}16,644 \\
(59 \%) \\
\end{array}$ & $\begin{array}{l}17,661 \\
(54 \%) \\
\end{array}$ \\
\hline 64425 & Ilio-Inguinal N.B. & $\begin{array}{l}5,557 \\
(55 \%) \\
\end{array}$ & $\begin{array}{l}5,555 \\
(52 \%) \\
\end{array}$ & $\begin{array}{l}5,550 \\
(55 \%) \\
\end{array}$ & $\begin{array}{l}6,212 \\
(47 \%) \\
\end{array}$ & $\begin{array}{l}7,022 \\
(43 \%) \\
\end{array}$ & $\begin{array}{l}5,122 \\
(44 \%) \\
\end{array}$ \\
\hline 64430 & Pudendal N.B. & $\begin{array}{c}757 \\
(38 \%) \\
\end{array}$ & $\begin{array}{r}532 \\
(32 \%) \\
\end{array}$ & $\begin{array}{c}750 \\
(33 \%) \\
\end{array}$ & $\begin{array}{l}2,185 \\
(23 \%) \\
\end{array}$ & $\begin{array}{l}5,445 \\
(15 \%) \\
\end{array}$ & $\begin{array}{l}5,519 \\
(16 \%) \\
\end{array}$ \\
\hline 64435 & Paracervical N.B. & $\begin{array}{l}1,926 \\
(15 \%) \\
\end{array}$ & $\begin{array}{l}1,437 \\
(06 \%) \\
\end{array}$ & $\begin{array}{l}1,809 \\
(14 \%) \\
\end{array}$ & $\begin{array}{l}1,850 \\
(21 \%) \\
\end{array}$ & $\begin{array}{c}1,971 \\
((21 \%) \\
\end{array}$ & $\begin{array}{c}753 \\
(23 \%) \\
\end{array}$ \\
\hline 64445 & Sciatic N.B. & $\begin{array}{c}22,513 \\
(14 \%) \\
\end{array}$ & $\begin{array}{c}19,488 \\
(16 \%)\end{array}$ & $\begin{array}{c}19,883 \\
(17 \%)\end{array}$ & $\begin{array}{c}22,195 \\
(16 \%) \\
\end{array}$ & $\begin{array}{c}26,238 \\
(19 \%)\end{array}$ & $\begin{array}{c}27,779 \\
(23 \%)\end{array}$ \\
\hline 64450 & Peripheral N.B. & $\begin{array}{c}127,904 \\
(17 \%)\end{array}$ & $\begin{array}{c}122,147 \\
(17 \%) \\
\end{array}$ & $\begin{array}{c}124,154 \\
(19 \%) \\
\end{array}$ & $\begin{array}{c}119,234 \\
(22 \%) \\
\end{array}$ & $\begin{array}{c}159,530 \\
(21 \%) \\
\end{array}$ & $\begin{array}{c}159,139 \\
(16 \%) \\
\end{array}$ \\
\hline 64505 & \begin{tabular}{|l|}
$\begin{array}{l}\text { Sphenopalatine ganglion } \\
\text { block }\end{array}$ \\
\end{tabular} & $\begin{array}{l}6,532 \\
(08 \%) \\
\end{array}$ & $\begin{array}{l}5,894 \\
(06 \%) \\
\end{array}$ & $\begin{array}{l}5,606 \\
(08 \%) \\
\end{array}$ & $\begin{array}{c}4,862 \\
(7 \%) \\
\end{array}$ & $\begin{array}{c}4,885 \\
(9 \%) \\
\end{array}$ & $\begin{array}{c}4,757 \\
(8 \%) \\
\end{array}$ \\
\hline 64510 & Stellate ganglion block & $\begin{array}{c}12,968 \\
(81 \%)\end{array}$ & $\begin{array}{l}11,626 \\
(82 \%)\end{array}$ & $\begin{array}{l}9,950 \\
(80 \%)\end{array}$ & $\begin{array}{l}9,473 \\
(81 \%) \\
\end{array}$ & $\begin{array}{c}10,233 \\
(77 \%) \\
\end{array}$ & $\begin{array}{l}9,589 \\
(73 \%) \\
\end{array}$ \\
\hline 64520 & L/T sympathetic block & $\begin{array}{l}14,637 \\
(68 \%) \\
\end{array}$ & $\begin{array}{c}12,903 \\
(63 \%) \\
\end{array}$ & $\begin{array}{c}12,254 \\
(73 \%) \\
\end{array}$ & $\begin{array}{l}12,522 \\
(69 \%) \\
\end{array}$ & $\begin{array}{r}16,099 \\
(58 \%) \\
\end{array}$ & $\begin{array}{l}12,135 \\
(69 \%) \\
\end{array}$ \\
\hline 64530 & Celiac plexus block & $\begin{array}{l}1,538 \\
(88 \%) \\
\end{array}$ & $\begin{array}{l}1,329 \\
(90 \%) \\
\end{array}$ & $\begin{array}{l}1,348 \\
(92 \%) \\
\end{array}$ & $\begin{array}{l}1,334 \\
(89 \%) \\
\end{array}$ & $\begin{array}{l}1,366 \\
(88 \%) \\
\end{array}$ & $\begin{array}{l}1,608 \\
(86 \%) \\
\end{array}$ \\
\hline 64600 & Trigeminal neurolysis & $\begin{array}{c}735 \\
(58 \%) \\
\end{array}$ & $\begin{array}{c}772 \\
(51 \%) \\
\end{array}$ & $\begin{array}{c}577 \\
(58 \%) \\
\end{array}$ & $\begin{array}{c}655 \\
(47 \%) \\
\end{array}$ & $\begin{array}{c}701 \\
(52 \%) \\
\end{array}$ & $\begin{array}{c}647 \\
(43 \%) \\
\end{array}$ \\
\hline 64605 & Trigeminal neurolysis & $\begin{array}{c}209 \\
(67 \%) \\
\end{array}$ & $\begin{array}{c}191 \\
(60 \%) \\
\end{array}$ & $\begin{array}{c}164 \\
(46 \%) \\
\end{array}$ & $\begin{array}{c}54 \\
(100 \%) \\
\end{array}$ & $\begin{array}{c}38 \\
(100 \%) \\
\end{array}$ & $\begin{array}{c}82 \\
(66 \%) \\
\end{array}$ \\
\hline 64610 & Trigeminal neurolysis & $\begin{array}{c}561 \\
(100 \%) \\
\end{array}$ & $\begin{array}{c}698 \\
(100 \%)\end{array}$ & $\begin{array}{c}597 \\
(100 \%) \\
\end{array}$ & $\begin{array}{c}509 \\
(100 \%)\end{array}$ & $\begin{array}{c}615 \\
(100 \%) \\
\end{array}$ & $\begin{array}{c}546 \\
94 \%) \\
\end{array}$ \\
\hline 64613 & $\begin{array}{l}\text { Chemodenervation C } \\
\text { spinal muscle }\end{array}$ & $\begin{array}{c}16,606 \\
(18 \%)\end{array}$ & $\begin{array}{l}11,988 \\
(25 \%) \\
\end{array}$ & $\begin{array}{l}14,136 \\
(25 \%) \\
\end{array}$ & $\begin{array}{l}18,957 \\
(24 \%) \\
\end{array}$ & $\begin{array}{c}25,190 \\
(20)\end{array}$ & $\begin{array}{c}29,960 \\
(18 \%)\end{array}$ \\
\hline 64620 & Intercostal neurolysis\# & $\begin{array}{l}1,752 \\
(86 \%) \\
\end{array}$ & $\begin{array}{l}1,755 \\
(85 \%) \\
\end{array}$ & $\begin{array}{r}2,141 \\
(87 \%) \\
\end{array}$ & $\begin{array}{l}1,862 \\
(85 \%) \\
\end{array}$ & $\begin{array}{l}2,003 \\
(78 \%) \\
\end{array}$ & $\begin{array}{l}2,213 \\
(72 \%) \\
\end{array}$ \\
\hline 64630 & Pudendal nerve neurolysis & $\begin{array}{c}16 \\
(100 \%) \\
\end{array}$ & $\begin{array}{c}16 \\
(100 \%) \\
\end{array}$ & $\begin{array}{c}30 \\
(100 \%) \\
\end{array}$ & $\begin{array}{c}97 \\
(11 \%)\end{array}$ & $\begin{array}{c}340 \\
(19 \%) \\
\end{array}$ & $\begin{array}{l}293 \\
(9 \%) \\
\end{array}$ \\
\hline 64640 & Peripheral neurolysis & $\begin{array}{c}17,375 \\
(46 \%)\end{array}$ & $\begin{array}{c}20,933 \\
(31 \%)\end{array}$ & $\begin{array}{l}25,910 \\
(28 \%)\end{array}$ & $\begin{array}{l}31,529 \\
(22 \%)\end{array}$ & $\begin{array}{c}76,280 \\
(13 \%) \\
\end{array}$ & $\begin{array}{c}94,648 \\
(9 \%)\end{array}$ \\
\hline \multirow[t]{2}{*}{64680} & Celiac plexus neurolysis & $\begin{array}{l}1,129 \\
(94 \%) \\
\end{array}$ & $\begin{array}{l}1,020 \\
(90 \%) \\
\end{array}$ & $\begin{array}{l}1,227 \\
(88 \%) \\
\end{array}$ & $\begin{array}{l}1,247 \\
(77 \%) \\
\end{array}$ & $\begin{array}{r}1,387 \\
(54 \%) \\
\end{array}$ & $\begin{array}{l}1,708 \\
(47 \%) \\
\end{array}$ \\
\hline & Total & $\begin{array}{c}329,552 \\
(33 \%) \\
\end{array}$ & $\begin{array}{c}313,415 \\
(33 \%) \\
\end{array}$ & $\begin{array}{c}324,320 \\
(35 \%) \\
\end{array}$ & $\begin{array}{c}343,277 \\
(35 \%) \\
\end{array}$ & $\begin{array}{c}457,219 \\
(30 \%) \\
\end{array}$ & $\begin{array}{c}490,337 \\
(28 \%) \\
\end{array}$ \\
\hline
\end{tabular}

Source: Utilization data By Specialty from CMS (ref. 89)

() shows percentage of procedures utilized in facility settings (HOPD and ASC) 


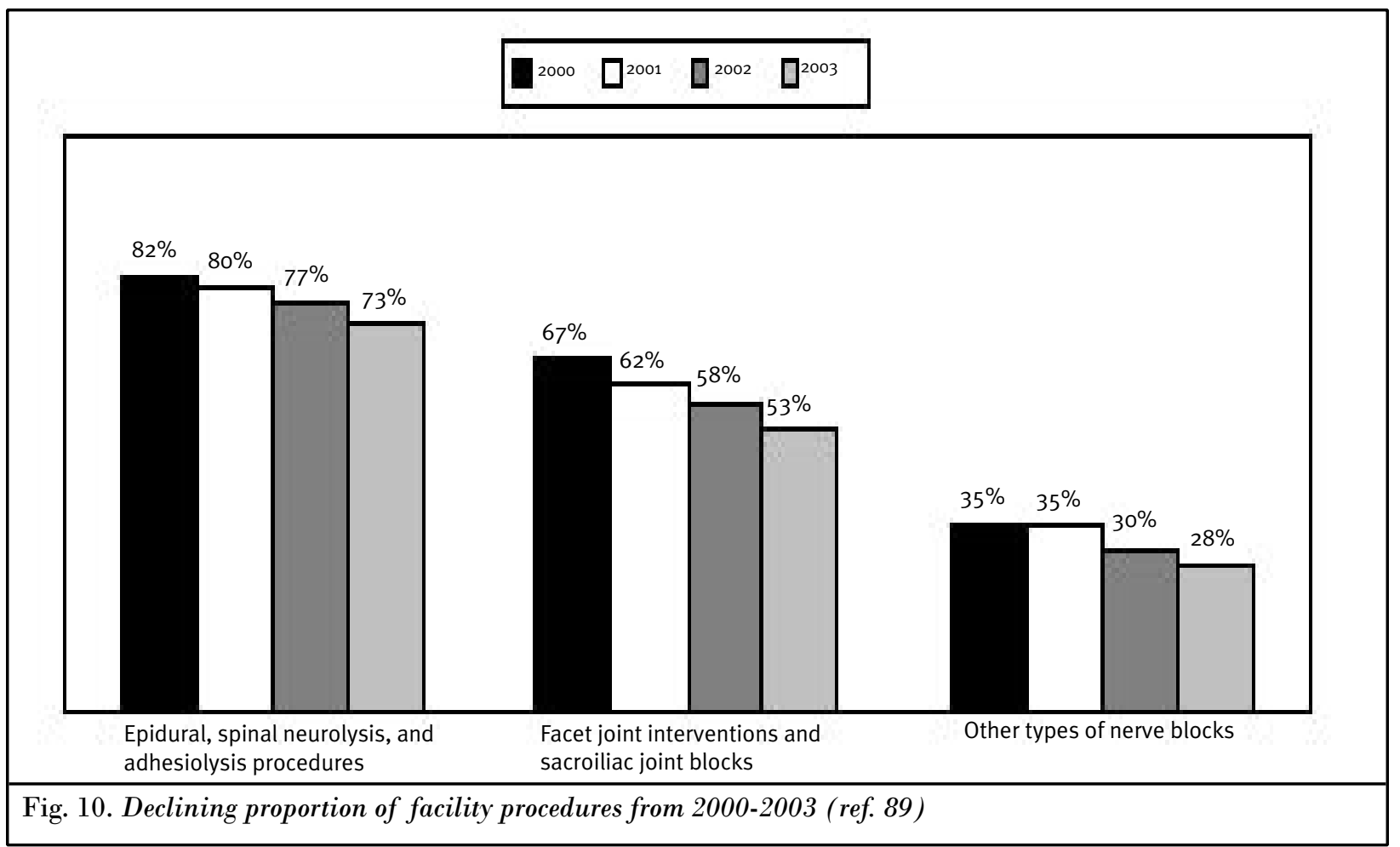

studies by primary care providers for low back pain concluded that orders for magnetic resonance imaging (MRI) did not decrease based on guidelines. Yet, others (92-94) indicated that implementation of selective ordering criteria proposed by national authorities (95), resulted in increased utilization of lumbar spine radiographs. With reference to interventional techniques, in a study of 300 patients, the results showed that there was significant improvement in patient outcomes with a decrease in the number of visits per year, average expenditure per visit and per year following 2001 published guidelines for interventional techniques $(96,97)$.

\section{ConcLusion}

In 2005 and beyond, interventionalists will face an array of evolving issues, including CPT coding, correct coding issues, and utilization patterns. It is of paramount importance for interventionalists to be aware of the changes in coding patterns, and diligently follow billing and coding regulations, and correct coding initiatives. Appropriate documentation of medical necessity is required for each and every procedure. It is essential to establish and follow an algorithmic approach in interventional pain management practice. In conjunction with the algorithmic ap- proach, the application of clinical guidelines may provide quality care and reduce the likelihood of investigations.

\section{Author Affiliation:}

Laxmaiah Manchikanti, MD

Medical Director

Pain Management Center of Paducah

Assistant Clinical Professor of

Anesthesiology and Perioperative

Medicine

University of Louisville, KY

2831 Lone Oak Road

Paducah, Kentucky 42003

E-mail:drm@apex.net

\section{REFERENCES}

1. Brown DL, Fink BR. The history of neural blockade and pain management. In Cous ins MJ, Bridenbaugh PO (eds). Neural Blockade in Clinical Anesthesia and Management of Pain. 3rd ed. Lippincott Raven, Philadelphia, 1998, pp. 3-34.

2. Tuffer T. Anesthésie medullaire chirurgicale par injection sousarachnoidienne lombiare de cocaine; technique et resultats. Semaine Medicale 1900; 20:167.

3. Cushing $\mathrm{H}$. On the avoidance of shock in major amputations by cocainization of large nerve-trunks preliminary to their division. Ann Surg 1902; 36:321.

4. Sicard MA. Les injections medicamenteuse extraduraqles per voie saracoccygiene.
Comptes Renues des Senances de la Societe de Biolgie et de ses Filliales, 1901; 53:396-398.

5. Cathelin F. Mode d'action de a cocaine in jete daus l'escapte epidural par le procede du canal sacre. Comptes Rendies des Senaces de la Societe de Biologic et de ses Filliales, 1901; 53:452-453.

6. Pasquier NM, Leri D. Injection intra et extradurales de cocaine a dose minime daus le traitment de la sciatique. Bull Gen Ther 1901; 142:196.

7. Schloesser H. Heilung periphärfer Reizzustände sensibler und motorischer Nerven. Klin Monatsbl Augenheilkd 1903; 41: 255.

8. Brunn F, Mandl F. Die paravertebral Injektion zur Bekäampfung visceraler Schmerzen. Wien Klin Wochenschr 1924; 37:511.

9. Royle ND. A new operative procedure in the treatment of spastic paralysis and its experimental basis. Med J Aust 1924; 1: 77.

10. Swetlow GI. Paravertebral alcohol block in cardiac pain. Am Heart J 1926; 1:393.

11. Sise LF. Spinal anesthesia for upper and lower abdominal operations. N Engl J Med 1928; 199:61.

12. Kappis M. ueber Leitungsanästhesie an Bauch, Burst, Arm und Hals durch Injektion ans Foramen intervertebrale. Münch. Med Wochenschr 1912; 1:794.

13. Läwen A. Ueber segmentäre Schmerzaufhebung durch papavertebrale Novokaininjektionen zur Differentialdiagnose intraadbominaler Erkrankungen. Med Wochenschr 1922; 69:1423. 
14. Braun H. Ueber einige neuer örtliche Anaesthetica (Stovain, Alypin, Novocain). Dtsch Klin Wochenschr 1905; 31:1667.

15. Kappis M, Erfahrungen mit Lokalanästhesie bei Bauchoperationen. Verh Dtsch Ges Chir 1914; 43:87.

16. Wertheim HM, Rovenstine EA. Suprascapular nerve block. Anesthesiology 1941; 2: 541.

17. Caussade G, Queste P. Traitement de al neuralgie sciatique par la mèthode de Sicard. Résultats favorables même dans les cas chroniues par la cocaïne à doses élevées et répétées à intervalles raproches. Bull Soc Med Hosp Paris 1909; 28:865.

18. Sicard JA, Forestier J: Methode radiographique d'exploration de la cavite epidurale par le Lipiodol. Rev Neurol 1921; 2:1264.

19. Viner N. Intractable sciatica. The sacral epidural injection: An effective method of giving pain relief. Can Med Asso J 1925; 15: 630-634.

20. Evans W. Intersacral epidural injection in the treatment of sciatica. Lancet 1930; 2 : 1225-1229.

21. Cappio M. Il trattamento idrocortisonico per via epidurale sacrale delle lombosciatalgie. Reumatismo 1957; 9:60-70.

22. Brown JH. Pressure caudal anesthesia and back manipulation. Northwest Med 1960; 59: 905-909.

23. Cyriax JH. Epidural anesthesia and bedrest in sciatica. Br Med J 1961; 1:20-24.

24. Goebert HW, Jallo SJ, Gardner WJ et al. Painful radiculopathy treated with epidural injections of procaine and hydrocortisone acetate: Results in 113 patients. Anesth Analg 1961; 140:130-134.

25. Bogduk N, Christophidis N, Cherry D et al. Epidural Use of Steroids in the Management of Back Pain. Report of Working Party on Epidural Use of Steroids in the Management of Back Pain. National Health and Medical Research Council. Commonwealth of Australia, Canberra, 1994, pp 176.

26. Robechhi A, Capra R. L'idrocortisone (composto F). Prime esperienze cliniche in campo reumatologico. Minerva Med 1952; 98: 1259-1263.

27. Biella A, Cocognini P. L'acetato di idrocortisone nel trattamento della sindrome sciatalgica. Minerva Med 1954; 1:1863-1865.

28. Cappio M, Fragasso V. Osservazioni sull'uso dell'idroscortisone per via eidurale ed endorachidea nelle lombosciatalgie. Riforma Med 1955; 22:605-607.

29. Cappio M, Fragasso V. Il prednisone per via epidurale sacrale nelle lombosciatalgie. Reumatismo 1957; 5:295-298.

30. Lievre JA, Block-Mechel H, Pean G, et al. L'hydrocortisone en injection locale. Rev Rhum 1953; 20:310-311.

31. Gilly R. essai de traitement de 50 cas de sciatiques et de radiculalgies lombaires par le Clestene chronodose en infiltrations paradiculaire. Marseille Medicale 1970; 107:341-345.

32. Tajima T, Furukawa K, Kuramochi E. Selective lumbosacral radiculography and block. Spine 1980; 5:68-77.

33. Racz GB, Holubec JT. Lysis of adhesions in the epidural space. In Racz GB (ed), Techniques of Neurolysis. Kluwer Academic Publishers, Boston, 1989, pp 57-72.

34. Racz GB, Haynsworth RF, Lipton S. Experiences with an improved epidural catheter. Pain Clinic 1986; 1:21-27.

35. Goldthwait JE. The lumbosacral articulation: an explanation of many cases of lumbago, sciatica, and paraplegia. Boston Med and Surg J 1911; 164:365-372.

36. Hirsch D, Inglemark B, Miller M. The anatomical basis for low back pain. Acta Orthop Scand 1963; 33:1.

37. Mooney V, Robertson J. The facet syndrome. Clin Orthop 1976; 115:149-156.

38. McCall IW, Park WM, O’Brien JP. Induced pain referral from posterior elements in normal subjects. Spine 1979; 4:441-446.

39. Bogduk N, Marsland A. The cervical zyg apophyseal joints as a source of neck pain. Spine 1988; 13:610-617.

40. Kuslich SD, Ulstrom CL, Michael CJ. The tissue origin of low back pain and sciatica: $A$ report of pain response to tissue stimulation during operation on the lumbar spine using local anesthesia. Orthop Clin North Am 1991; 22:181-187.

41. Dwyer A, Aprill C, Bogduk N. Cervical zygapophyseal joint pain patterns: a study in normal volunteers. Spine 1990; 6:453457.

42. Dreyfuss P, Tibiletti C, Dreyer SJ. Thoracic zygapophyseal joint pain patterns: a study in normal volunteers. Spine 1994; 19:807811.

43. Aprill C, Dwyer A, Bogduk N. The prevalence of cervical zygapophyseal joint pain patterns II: a clinical evaluation. Spine 1990;6:458-461.

44. Manchikanti L, Singh V, Pampati V et al. Evaluation of the relative contributions of various structures in chronic low back pain. Pain Physician 2001; 4:308-316.

45. Shealy $\mathrm{CN}$. Percutaneous radiofrequency denervation of the lumbar facets. I Neurosurg 1975; 43:448-451.

46. von Gaza W. Die Resektion der paravertebralen Nerven und die isolierte Durchschneidung des Ramus communicans. Arch Klin Chir 1924; 133:479.

47. White JC. Diagnostic novocaine block of the sensory and sympathetic nerves. A method of estimating the results which can be obtained by their permanent interruption. Am J Surg 1930; 9:264.

48. Steindler A, Luck JV. Differential diagnosis of pain in the low back: Allocation of the source of the pain by the procaine hydrochloride method. JAMA 1938; 110:106-113.

49. Bogduk N. The clinical anatomy of the cervical dorsal rami. Spine 1982; 7:35-45.

50. Bogduk N. Clinical Anatomy of the Lumbar
Spine and Sacrum. Ed. 3. Churchill Livingstone, New York, 1997.

51. Bogduk N. Low back pain. In Clinical Anatomy of the Lumbar Spine and Sacrum, ed 3. Churchill Livingstone, New York, 1997; pp 187-214.

52. Kuslich SD, Ulstrom CL, Michael CJ. The tissue origin of low back pain and sciatica: $A$ report of pain response to tissue stimulation during operation on the lumbar spine using local anesthesia. Orthop Clin North Am 1991; 22:181-187.

53. Manchikanti L, Singh V, Fellows B. Structural basis of chronic low back pain. In Manchikanti L, Slipman CW, Fellows B (eds), Interventional Pain Management: Low Back Pain - Diagnosis and Treatment. ASIPP Publishing, Paducah, KY 2002; 7796.

54. Cavanaugh JM, Ozaktay AC, Yamashita T et al. Mechanisms of low back pain: A neurophysiologic and neuroanatomic study. Clin Orthop 1997; 335:166-180.

55. Bogduk N, Wilson AS, Tynan W. The human lumbar dorsal rami. J Anat 1982; 134:383397.

56. Bogduk N. The innervation of the lumbar spine. Spine 1983; 8:286-293.

57. Chua WH, Bogduk N. The surgical anatomy of thoracic facet denervation. Acta Neurochir 1995; 136:140-144.

58. Bogduk N, Windsor $M$, Inglis $A$. The innervation of the cervical intervertebral discs. Spine 1988; 13:2-8.

59. Mendel T, Wink CS, Zimny ML. Neural elements in human cervical intervertebral discs. Spine 1992; 17:132-135.

6o. Bogduk N, Tynan W, Wilson AS. The innervation of the human lumbar intervertebral discs. J Anat 1981; 132:39-56.

61. Fortin JD, Kissling RO, O'Connor BL et al. Sacroiliac joint innervation and pain. $\mathrm{Am}$ J Orthop 1999; 28:687-690.

62. Fortin JD, Dwyer AP, West S, Pier J. Sacroiliac joint. Pain referral maps upon applying a new injection/arthrography technique. Part I. Asymptomatic volunteers. Spine 1994 19: 1475-1482.

63. Fortin JD, Aprill CN, Ponthieux B et al. Sacroiliac joints: Pain referral maps upon applying a new injection/arthrography technique. Part II: Clinical evaluation. Spine 1994; 19:1483-1489.

64. Bogduk N, McGuirk B. Treatment strategies. In Medical Management of Acute and Chronic Low Back Pain. An Evidence Based Approach Pain Research and Clinical Management. Vol 13. Elsevier Science, Amsterdam, 2002, pp 139-142.

65. Bogduk N, McGuirk B. An algorithm for precision diagnosis. In Medical Management of Acute and Chronic Low Back Pain. An Evidence Based Approach Pain Research and Clinical Management. Vol 13. Elsevier Science, Amsterdam, 2002, pp 177-186.

66. Loeser JD. Mitigating the dangers of pursuing care. In Pain Treatment Centres at 
a Crossroads: A Practical and Conceptual Reappraisal, Progress in Pain Management, Vol. 7. IASP Press, Seattle, 1996, pp 101-108.

67. Manchikanti L, Staats PS, Singh V et al. Evidence-based practice guidelines for interventional techniques in the management of chronic spinal pain. Pain Physician 2003; 6:3-80.

68. Boswell MV, Singh V, Staats PS et al. Accuracy of precision diagnostic blocks in the diagnosis of chronic spinal pain of facet or zygapophysial joint pain. Pain Physician 2003; 6:449-456.

69. Boswell MV, Hansen HC, Trescot AM et al. Epidural steroids in the management of chronic spinal pain and radiculopathy. Pain Physician 2003; 6:319-334.

70. Manchikanti L, Singh V, Vilims BD et al. Medial branch neurotomy in management of chronic spinal pain: Systematic review of the evidence. Pain Physician 2002; 5: 405-418.

71. Manchikanti L, Rivera JJ, Pampati V et al. One day lumbar epidural adhesiolysis and hypertonic saline neurolysis in treatment of chronic low back pain: A randomized, double-blind trial. Pain Physician 2004; 7 : 177-186.

72. Heavner JE, Racz GB, Raj P. Percutaneous epidural neuroplasty. Prospective evaluation of $0.9 \% \mathrm{NaCl}$ versus $10 \% \mathrm{NaCl}$ with or without hyaluronidase. Reg Anesth Pain Med 1999; 24:202-207.

73. Manchikanti L, Singh V. Epidural lysis of adhesions and myeloscopy. Curr Pain Headache Rep 2002; 6:427-435.

74. Manchikanti L, Rivera J, Pampati VS et al. Spinal Endoscopic Adhesiolysis in the Management of Chronic Low Back Pain: A Preliminary Report of A Randomized, Double-Blind Trial. Pain Physician 2003; 6 259-268.

75. Manchikanti L, Boswell MV, Singh V et al. Prevalence of facet joint pain in chronic spinal pain of cervical, thoracic, and lum- bar regions. BMC Musculoskelet Disord 2004; 5:15.

76. Manchikanti L, Boswell MV. The complex world of documentation. In Principles of Documentation, Billing, Coding, and Practice Management, ASIPP Publishing, Paducah KY 2004.

77. Manchikanti L, Boswell MV. Understanding coverage determinations. In Principles of Documentation, Billing, Coding, and Practice Management, ASIPP Publishing, Paducah KY 2004.

78. Quinn C. Issues of medical necessity. A medical director's guide to good faith adjudication. Am J Managed Care 1997; 3: 883-888.

79. Manchikanti L, Boswell MV. Fraud and abuse in interventional pain management. In Principles of Documentation, Billing, Coding, and Practice Management, ASIPP Publishing, Paducah KY 2004.

80. Current Procedural Terminology. CPT 2000, American Medical Association, Chicago, 1999.

81. Current Procedural Terminology. CPT 2001, American Medical Association, Chicago, 2000.

82. Current Procedural Terminology. CPT 2002, American Medical Association, Chicago, 2001.

83. Current Procedural Terminology. CPT 2003, American Medical Association, Chicago, 2002.

84. Current Procedural Terminology. CPT 2004, American Medical Association, Chicago, 2003.

85. Current Procedural Terminology. CPT 2005, American Medical Association, Chicago, 2004.

86. Manchikanti L, Fellows B. General correct coding policies. In Principles of Documentation, Billing, Coding, and Practice Management, ASIPP Publishing, Paducah KY 2004.

87. Manchikanti L, Boswell MV. Correct cod- ing policies for interventional techniques. In Interventional Pain Management: Principles of Documentation, Billing, Coding, and Practice Management, ASIPP Publishing, Paducah KY 2004.

88. National Correct Coding Initiative Edits National Correct Coding Initiative Edits Version 10.3 for Physicians (Effective October 1, 2004 - December 31, 2004).

89. Specialty Utilization data files from CMS: http://www.cms.hhs.gov/physicians/pfs/

90. McGuirk B, King W, Govind J et al. Safety, efficacy, and cost effectiveness of evidence-based guidelines for the management of acute low back pain in primary care. Spine 2001; 26:2615-2622.

91. Walker RD, Howard MO, Lambert MD et al. Medical practice guidelines. West J Med 1994; 161:39-44.

92. Deyo RA, Diehl AK. Lumbar spine films in primary care: Current use and effects of selective ordering criteria. J Gen Intern Med 1986; 1:20-25.

93. Frazier L, Carey TS, Lyles MF et al. Selective criteria may increase lumbosacral spine roentgenogram use in acute low back pain. Arch Intern Med 1989; 149:4750.

94. Schroth WS, Schectman JM, Elinksy EG et al. Utilization of medical services for the treatment of acute low back pain: Conformance with clinical guidelines. J Gen Intern Med 1992; 7:486-492.

95. Deyo RA. Early diagnostic evaluation of low back pain. J Gen Intern Med 1986; 4 328-338.

96. Manchikanti L, Rivera JJ, Pampati V et al. Effectiveness of clinical guidelines in interventional pain management. Pain Physician 2002; 5:127-132.

97. Manchikanti L, Singh V, Kloth D et al. Interventional techniques in the management of chronic pain: Part 2.o. Pain Physician 2001; 4:24-96. 